\title{
PREDIKSI KEBIJAKAN UTANG, PROFITABILITAS, LIKUIDITAS, UKURAN, DAN STATUS PERUSAHAAN TERHADAP KEMUNGKINAN PENENTUAN PERINGKAT OBLIGASI: STUDI EMPIRIK PADA PERUSAHAAN YANG MENERBITKAN OBLIGASI DI BURSA EFEK INDONESIA
}

\author{
Bram Hadianto \\ Fakultas Ekonomi Jurusan Manajemen Universitas Kristen Maranatha Bandung \\ E-mail: tan han sin@hotmail.com, HP. 0817425350 \\ M. Sienly Veronica Wijaya \\ Fakultas Ekonomi Jurusan Manajemen Universitas Kristen Maranatha Bandung \\ E-mail: lee pingping@yahoo.com, HP. 08122106762
}

\begin{abstract}
.
The aim of this research is to know the prediction of debt policy, profitability, liquidity, size, and firm's status on bond rating, and to find the accuracy rate for classifying companies that have investment grade of bond rating and non investment grade of bond rating based on these given factors.

We employ logistic regression model as data analysis method. Our sample is taken from Indonesian Bonds Market Directory (IBMD) in the year of 2008 which collected by purposive sampling method. There are 105 listed bond's issuers until 2008. In our observation, there are 3 issuers that have no bond rating so that we use only 102 issuers as the sample.

The results show that profitability is the only explanatory variable which has significant impact on bond rating with positive sign and the accuracy rate of debt policy, profitability, liquidity, size, and firm's status to classify bond issuer category are as high as $85.3 \%$.
\end{abstract}

Keywords: bond rating, profitability, logistic regression model, classification matrix.

\section{PENDAHULUAN}

Salah satu fungsi keuangan utama yang dilakukan oleh manajer keuangan adalah membuat keputusan yang berkaitan dengan aktivitas pencarian dana (financing decision) (Sartono, 2001). Dalam memilih sumber dana yang digunakan, manajer akan berusaha mencari sumber dana yang mempunyai biaya paling murah pada tingkat risiko tertentu (Hanafi, 2004:4). Bagi perusahaan, pasar modal merupakan alternatif pendanaan eksternal dengan biaya yang lebih rendah dari pada sistem perbankan karena dapat menghilangkan biaya intermediasi (Husnan, 2009:7). Biaya intermediasi tidak lain merupakan spread/selisih antara tingkat bunga pinjaman yang dibebankan pada pihak debitur dengan tingkat bunga yang dibayarkan pada penabung (Hanafi, 2004:68). Jika perusahaan meminjam dana pada bank, maka selisih inilah yang harus sepenuhnya ditanggung oleh perusahaan (Husnan, 2009:7). Dengan kata lain, jika pendanaan dilakukan melalui pasar modal maka perusahaan tidak perlu menanggung spread tersebut.

Pasar modal juga merupakan sarana perusahaan untuk meningkatkan kebutuhan dana jangka panjang dengan menjual saham atau mengeluarkan obligasi (Hartono, 2008:25). Bagi 
perusahaan yang telah menjadi perusahaan publik, menerbitkan saham baru atau mengeluarkan obligasi tentu saja mendapatkan respon yang berbeda dari pasar. Martel dan Padron (2009) menyatakan secara empirik, pasar memberikan respon negatif terhadap penerbitan saham baru dan sebaliknya terhadap penerbitan obligasi. Respon positif ini dicerminkan atas kenaikan harga saham setelah penerbitan obligasi (Johnson, 1995; Martel dan Padron, 2006). ${ }^{1}$ Menurut Myers dan Maljuf (1984), dengan adanya informasi yang tidak simetris, investor biasanya akan menafsirkan sebagai berita yang buruk jika perusahaan mendanai investasinya dengan menerbitkan ekuitas sehingga terjadi penurunan harga saham perusahaan yang bersangkutan. Sartono (2008) mengemukakan dua argumen reaksi pasar mengenai hal ini. Pertama, penjualan saham baru merupakan sinyal bahwa perusahaan mengalami kesulitan keuangan, perusahaan memiliki struktur modal yang tidak baik, perusahaan berusaha untuk memperbaiki strukur modal, perusahaan ingin melakukan peningkatan kapasitas utang. Kedua, penjualan saham baru dipandang oleh pasar sebagai upaya pemilik untuk melakukan diversifikasi di bisnis yang lain karena bisnis saat ini sudah memiliki risiko yang tinggi.

Pilihan struktur keuangan mencerminkan ekspektasi manajemen terhadap prospek perusahaan. Manajer dengan keunggulan informasi memiliki insentif untuk memberikan sinyal berupa informasi privat melalui pemilihan tingkat utang yang digunakannya. Perusahaan dengan aliran kas yang rendah tidak menggunakan utang terlalu tinggi karena akan sangat mahal biayanya (Ross, 1977). Dengan kata lain, penerbitan obligasi memberikan sinyal bahwa perusahaan memiliki aliran kas yang tinggi sehingga pasar merespon positif terhadap peristiwa ini. Meskipun pasar merespon positif, namun tidak semua obligasi yang diterbitkan perusahaan memiliki reputasi yang baik. Kemampuan perusahaan dalam membayar bunga dan pokok pinjamannya menjadi salah satu indikator penilaian reputasi ini. Kemampuan tersebut tercermin lewat peringkat obligasi. Tandelilin (2010:251) menyatakan semakin tinggi peringkat obligasi, semakin rendah risiko yang dihadapi oleh investor mengingat semakin kecil kemungkinan obligasi mengalami kegagalan dalam membayar bunga dan pokok pinjamannya. Menurut Almalia dan Devi (2007), Amrullah (2007),

\footnotetext{
${ }^{1}$ Dalam penelitiannya, Johnson (1995) maupun Martel dan Padron (2006) menemukan pasar merespon positif terhadap penerbitan utang. Respon positif ini ditunjukkan oleh abnormal return yang positif setelah terjadinya penerbitan obligasi. Respon pasar yang positif ini ditemukan pada perusahaan dengan rasio pembayaran dividen yang rendah. Temuan mereka ini mendukung terjadinya hubungan subtitusi antara utang dan dividen (Jensen, 1986). Baik utang dan dividen sama-sama mengurangi aliran kas yang dipegang manajemen (Martel dan Padron, 2006). Penerbitan utang memunculkan konsekuensi bahwa perusahaan harus membayar pokok pinjaman dan bunga secara periodik (Curtchley dan Hansen, 1989). Dengan demikian, apabila aliran kas yang dimiliki perusahaan telah digunakan untuk memenuhi kewajiban tersebut maka perusahaan tidak dapat membagikan dividen dalam jumlah yang tinggi.
} 
Setyapurnama dan Norpratiwi (2009), terdapat dua kategori kelompok peringkat obligasi yaitu kategori kelas investasi (investment grade) dan kategori bukan kelas investasi (non investment grade). Berdasarkan pengamatan peneliti, perusahaan yang menerbitkan obligasi sampai dengan tahun 2008 ternyata tidak hanya perusahaan publik saja (perusahaan dengan status sebagai perusahaan terbuka, namun juga perusahaan non publik (perusahaan tanpa status sebagai perusahaan terbuka).

Tabel 1. Jumlah Perusahaan Penerbit Obligasi sampai Tahun 2008

\begin{tabular}{|l|c|c|c|}
\hline \multirow{2}{*}{$\begin{array}{c}\text { Status } \\
\text { Perusahaan }\end{array}$} & Jumlah & \multicolumn{2}{|c|}{ Jumlah Perusahaan dengan Kategori: } \\
\cline { 3 - 4 } & Perusahaan & Investment Grade & Non Investment Grade \\
\hline Publik & 61 & 51 & 10 \\
\hline Non Publik & 41 & 35 & 6 \\
\hline
\end{tabular}

Sumber: Lampiran 1 yang diolah kembali

Pada Tabel 1 terlihat terdapat 102 perusahaan penerbit obligasi yang memiliki peringkat obligasi, ${ }^{2}$ terdapat 61 perusahaan publik dan 41 perusahaan non-publik dengan rincian sebagai berikut.

- 61 perusahaan publik ini ternyata tidak semuanya berada dalam kategori peringkat obligasi kelas investasi, namun juga dalam kategori kelas bukan investasi. Keenampuluh satu perusahaan publik ini terklasifikasi pada 51 perusahaan dengan kategori peringkat kelas investasi dan 10 perusahaan dalam kategori peringkat kelas bukan investasi.

- $\quad 41$ perusahaan non-publik ini ternyata tidak semuanya berada dalam kategori peringkat obligasi kelas bukan investasi, namun juga dalam kategori kelas investasi. Keempat puluh satu perusahaan non-publik ini terklasifikasi pada 35 perusahaan dengan peringkat investasi dan 6 perusahaan dengan kategori bukan investasi.

Peringkat obligasi merupakan salah satu acuan bagi investor ketika akan memutuskan membeli obligasi (Manurung, Silitonga, dan Tobing, 2009). Oleh karenanya, beberapa faktor yang mempengaruhi peringkat obligasi menjadi perlu untuk diteliti. Faktor-faktor tersebut dapat berupa rasio keuangan (Kamstra, Kennedy, dan Suan, 2001; Crabtree dan Maher, 2005; Almalia dan Devi, 2007; Amrullah, 2007; Hasnawati dan Dirja, 2008; Purwaningsih, 2008; Raharja dan Sari, 2008; Manurung, et al., 2009; Setyapurnama dan Norpratiwi, 2009) maupun faktor bukan rasio keuangan seperti risiko sistematik (Kamstra, et al., 2001), ukuran perusahaan (Kamsta, et al., 2001; Crabtree dan Maher, 2005; Almalia dan Devi, 2007; Hasnawati dan Dirja, 2008; Setyapurnama dan Norpratiwi, 2009). Mengingat banyaknya

\footnotetext{
${ }^{2}$ Dari 105 perusahaan penerbit obligasi sampai dengan tahun 2008, ternyata diperoleh 3 (tiga) perusahaan tanpa adanya peringkat. Dengan demikian, terdapat 102 penerbit obligasi yang memiliki peringkat (lihat Lampiran 1).
} 
proksi rasio keuangan yang digunakan, maka tidak semua rasio keuangan yang digunakan peneliti terdahulu digunakan. Penelitian ini hanya memfokuskan rasio keuangan yang menujukkan ketidakkonsisten hasil temuan antarpeneliti sebelumnya seperti kebijakan utang, profitabilitas, likuiditas, dan ukuran perusahaan (selengkapnya ringkasan hasil temuan mereka dapat dilihat pada Tabel 2).

Tabel 2. Hasil Penelitian Terdahulu Mengenai Arah Prediksi Kebijakan Utang, Profitabilitas, Likuiditas, dan Ukuran Perusahaan Terhadap Peringkat Obligasi

\begin{tabular}{|c|c|c|c|c|}
\hline \multirow[b]{2}{*}{ Nama Peneliti } & \multicolumn{4}{|c|}{ Arah Prediksi Variabel Penjelas } \\
\hline & $\begin{array}{l}\text { Kebijakan } \\
\text { Utang }\end{array}$ & Profitabilitas & Likuiditas & $\begin{array}{c}\text { Ukuran } \\
\text { Perusahaan }\end{array}$ \\
\hline $\begin{array}{l}\text { Kamstra, et al. } \\
\text { (2001) }\end{array}$ & $\begin{array}{c}\text { Negatif } \\
\text { (Signifikan) }\end{array}$ & $\begin{array}{c}\text { Positif } \\
\text { (Signifikan) }\end{array}$ & n.a. & $\begin{array}{c}\text { Positif } \\
\text { (Signifikan) }\end{array}$ \\
\hline $\begin{array}{l}\text { Crabtree dan } \\
\text { Maher (2005) }\end{array}$ & $\begin{array}{c}\text { Negatif } \\
\text { (Signifikan) }\end{array}$ & $\begin{array}{c}\text { Positif } \\
\text { (Signifikan) } \\
\end{array}$ & n.a. & $\begin{array}{c}\text { Positif } \\
\text { (Signifikan) }\end{array}$ \\
\hline $\begin{array}{l}\text { Almalia dan Devi } \\
\text { (2007) }\end{array}$ & n.a. & $\begin{array}{c}\text { Positif (Tidak } \\
\text { Signifikan) }\end{array}$ & $\begin{array}{c}\text { Positif } \\
\text { (Signifikan) }\end{array}$ & $\begin{array}{l}\text { Negatif (Tidak } \\
\text { Signifikan) }\end{array}$ \\
\hline Amrullah (2007) & $\begin{array}{c}\text { Negatif } \\
\text { (Signifikan) }\end{array}$ & $\begin{array}{c}\text { Positif } \\
\text { (Signifikan) }\end{array}$ & n.a. & n.a. \\
\hline $\begin{array}{l}\text { Hasnawati dan Dirja } \\
(2008)\end{array}$ & $\begin{array}{c}\text { Negatif } \\
\text { (Signifikan) }\end{array}$ & $\begin{array}{c}\text { Positif }^{3} \\
\text { (Signifikan) }\end{array}$ & $\begin{array}{c}\text { Positif } \\
\text { (Signifikan) } \\
\end{array}$ & $\begin{array}{c}\text { Positif } \\
\text { (Signifikan) }\end{array}$ \\
\hline $\begin{array}{l}\text { Raharja dan Sari } \\
(2008)\end{array}$ & $\begin{array}{c}\text { Negatif } \\
\text { (Signifikan) }\end{array}$ & \multicolumn{2}{|c|}{$\begin{array}{l}\text { Dikeluarkan dari } \\
\text { model penelitian }\end{array}$} & n.a. \\
\hline $\begin{array}{l}\text { Setyapurnama dan } \\
\text { Norpratiwi (2009) }\end{array}$ & $\begin{array}{l}\text { Negatif (Tidak } \\
\text { Signifikan) }\end{array}$ & n.a. & n.a. & $\begin{array}{l}\text { Negatif (Tidak } \\
\text { Signifikan) }\end{array}$ \\
\hline $\begin{array}{l}\text { Manurung, et al., } \\
\text { (2009) }\end{array}$ & $\begin{array}{l}\text { Positif (Tidak } \\
\text { Signifikan) }\end{array}$ & $\begin{array}{c}\text { Positif } \\
\text { (Signifikan) }\end{array}$ & $\begin{array}{c}\text { Negatif } \\
\text { (Signifikan) }\end{array}$ & n.a. \\
\hline
\end{tabular}

Keterangan: n.a. $=$ not available $=$ variabel tidak diteliti, Tidak signifikan: Variabel tidak dapat digunakan untuk memprediksi sekalipun menunjukkan tanda positif maupun negatif.

Ketidakkonsistenan pada faktor-faktor yang mempengaruhi peringkat obligasi inilah yang mendorong peneliti untuk melakukan verifikasi ulang atas keterkitan kebijakan utang, profitabilitas, likuiditas, dan ukuran perusahaaan dengan peringkat obligasi. Berbeda dengan penelitian Manurung, et al. (2009) yang menggunakan model kuadrat terkecil/ordinary least square (OLS), penelitian ini menggunakan model prediksi keanggotaan kelompok. Keistimewaan model prediksi keanggotaan kelompok yang tidak dimiliki oleh model OLS, terletak pada kemampuannya dalam mengukur ketepatan/akurasi klasifikasi pengelompokkan perusahaan berdasarkan kategori peringkat obligasi dengan mengunakan faktor-faktor

\footnotetext{
${ }^{3}$ Penelitian Hasnawati dan Dirja (2008) ini tidak menggunakan ROA dalam memprediksi peringkat obligasi. Berbeda dengan para peneliti lainnya yang menggunakan ROA, proksi profitabilitas yang digunakan dalam penelitian mereka yaitu ROE (return on equity).

${ }^{4}$ Kedua variabel ini sempat digunakan, namun karena penelitian tersebut hanya berusaha mengidentifikasi variabel yang berpengaruh secara signifikan terhadap kemungkinan pemeringkatan obligasi maka kedua variabel tersebut dikeluarkan dari model penelitian.
} 
penjelas yang digunakan. Selain mengacu pada ketidakkonsistenan hasil temuan para peneliti terdahulu mengenai faktor-faktor tersebut, peneliti berusaha untuk menambahkan satu faktor yang diperkirakan memiliki keterkaitan dengan peringkat obligasi yaitu status perusahaan yaitu perusahaan publik maupun non-publik. Status perusahaan ini digunakan mengingat berdasarkan pengamatan peneliti pada Tabel 1, ditemukan bukti bahwa perusahaan yang menerbitkan obligasi bukan hanya perusahaan publik (dengan status sebagai perusahaan terbuka), namun juga perusahaan tanpa status sebagai perusahaan terbuka.

Penelitian bertujuan untuk mengetahui: (1) arah prediksi kebijakan utang, likuiditas, ukuran perusahaan, dan status perusahaan terhadap kemungkinan penentuan peringkat obligasi, (2) besarnya akurasi pengklasifikasian emiten pada kategori peringkat obligasi kelas investasi (investment grade) maupun bukan kelas investasi (non-investement grade) berdasarkan kebijakan utang, profitabilitas, likuiditas, ukuran perusahaan, dan status perusahaan. Penelitian ini disusun dengan urut-urutan penyajian sebagai berikut. Bagian kedua menyajikan: (1) kerangka teori mengenai peringkat obligasi dan (2) pengembangan hipotesis mengenai keterkaitan antara kebijakan utang, profitabilitas, likuiditas, ukuran perusahaan, dan status perusahaan dengan peringkat obligasi. Bagian ketiga mengetengahkan metode penelitian yang digunakan dalam penelitian ini. Adapun penjelasan metode penelitian mencakup jenis penelitian, operasionaliasasi variabel penelitian, data dan sampel. Bagian keempat mengetengahkan hasil penelitian dan pembahasan yang meliputi: (1) deskripsi statistika sampel yang digunakan, (2) model penelitian yang digunakan, (3) pengujian hipotesis dan pembahasan, dan (4) hasil prediksi matriks klasifikasi. Bagian terakhir berisi kesimpulan hasil penelitian dan saran relevan yang ditujukkan bagi pihak-pihak terkait.

\section{TINJAUAN TEORI DAN PENGEMBANGAN HIPOTESIS \\ Peringkat Obligasi}

Peringkat obligasi merupakan simbol-simbol karakter yang diberikan oleh agen peringkat untuk menunjukkan risiko obligasi. Peringkat obligasi ini dikeluarkan oleh agen pemeringkat obligasi. Dua buah agen peringkat obligasi yang terkenal di dunia yaitu Standard \& Poor's Corporation (S\&P) dan Moody's Investor Service Inc. (Hartono, 2008:166). Di Indonesia, peringkat obligasi ditentukan oleh PT Pemeringkat Efek Indonesia (PEFINDO) yang dalam prakteknya bekerja sama dengan Standard \& Poor's Corporation (S\&P) (Sartono, 2008:71) maupun PT Kasnic Credit Rating Indonesia (KCRI) (Hartono, 2008:166). Baik S\&P, Moody, PEFINDO, maupun KCRI mengklasifikasi peringkat obligasi dengan empat kategori. Keempat kategori obligasi tersebut yaitu kategori kualitas sangat tinggi, kategori 
kualitas tinggi, kategori spekulatif, dan kategori sangat buruk (Karyani dan Manurung, 2006).

Adapun jenis kategori peringkat obligasi dan simbolnya dapat dilihat pada Tabel 3.

Tabel 3. Klasifikasi Kategori Peringkat Obligasi oleh Lembaga Pemeringkat Obligasi

\begin{tabular}{|c|c|c|c|c|}
\hline $\begin{array}{c}\text { Lembaga } \\
\text { Pemeringkat } \\
\text { Obligasi }\end{array}$ & $\begin{array}{c}\text { Kualitas Sangat } \\
\text { Tinggi (Investment } \\
\text { Grade) }\end{array}$ & $\begin{array}{c}\text { Kualitas Tinggi } \\
\text { (Investment } \\
\text { Grade) }\end{array}$ & $\begin{array}{c}\text { Spekulatif (Non } \\
\text { Investment } \\
\text { Grade) }\end{array}$ & $\begin{array}{c}\text { Sangat Buruk } \\
\text { (Non Investment } \\
\text { Grade) }\end{array}$ \\
\hline S \& P & AAA dan AA & A dan BBB & BB dan B & CCC dan D \\
\hline Moody & Aaa dan Aa & A dan Baa & Ba dan B & Caa dan C \\
\hline PEFINDO & id.AAA dan id.AA & id.A dan id.BBB & id.BB dan id.B & $\begin{array}{c}\text { id.CCC, id.SD, } \\
\text { dan id.D }\end{array}$ \\
\hline KCRI & AAA dan AA & A dan BBB & BB dan B & CCC dan D \\
\hline
\end{tabular}

Sumber: Karyani dan Manurung (2006)

Secara umum, metodologi pemeringkatan PEFINDO untuk sektor korporasi, mencakup tiga risiko utama penilaian, yaitu risiko industri, risiko bisnis, dan risiko finansial (Pefindo, 2010). Berikut merupakan penjelasan atas tiga risiko tersebut.

1. Penilaian risiko industri. Penilaian risiko ini didasarkan pada lima faktor risiko utama, yaitu:

a. Pertumbuhan industri dan stabilitas. Hal ini terkait dengan kondisi permintaan dan penawaran, prospek, peluang pasar (ekspor versus domestik), tahapan industri (awal, pengembangan, matang, atau penurunan), dan jenis produk (produk yang bersifat pelengkap versus produk yang bisa disubstitusi, umum versus khusus, dan komoditas versus differensiasi).

b. Pendapatan dan struktur biaya. Hal ini mencakup pemeriksaan komposisi aliran pendapatan (rupiah versus US dollar), kemampuan untuk menaikkan harga (kemampuan untuk dengan mudah meneruskan kenaikan biaya kepada pelanggan/para pengguna akhir), tenaga kerja dan bahan baku, struktur biaya dan komposisinya (rupiah vs US dolar), komposisi biaya tetap versus biaya variabel, dan pengadaan bahan baku industri (domestik versus impor).

c. Hambatan masuk dan tingkat persaingan dalam industri. Hal ini mencakup penilaian terhadap karakteristik industri (padat modal, padat karya, terfragmentasi, menyebar, diatur ketat, dan sebagainya) untuk menentukan tingkat kesulitan masuk bagi para pemain baru. Penilaian juga mencakup analisis jumlah pemain dalam industri (global vs domestik), pesaing terdekat (domestik vs global), potensi perang harga (domestik vs global), dan lain-lain untuk mengetahui tingkat kompetisi yang ada pada saat ini dan yang akan datang. 
d. Regulasi dan deregulasi industri (sudut pandang peraturan). Hal ini terkait dengan pembatasan jumlah pemain, lisensi, kebijakan pajak (ekspor, impor, kuota, tarif, bea, cukai, dan lain-lain), kebijakan harga pemerintah (peraturan pemerintah Indonesia mengatur harga di beberapa sektor seperti listrik, jalan tol, dan telepon), dan persyaratan lingkungan (khususnya untuk sektor pertambangan).

e. Profil keuangan dari industri. Hal ini terkait dengan analisis atas beberapa tolok ukur keuangan yang diambil dari beberapa perusahaan besar dalam industri yang sebagian besar dapat mewakili industri masing-masing. Analisis kinerja keuangan industri meliputi analisis marjin, keuntungan, leverage, serta perlindungan arus kas.

2. Penilaian risiko bisnis. Penilaian risiko profil bisnis perusahaan sedikit berbeda antara satu perusahaan dengan perusahaan yang lain. Hal ini tergantung pada faktor-faktor kunci kesuksesan industri dimana perusahaan tersebut digolongkan. Industri-industri tersebut diklasifikasikan menjadi dua bagian besar:

a. Industri keuangan, terdiri perusahaan seperti bank, perusahaan multi pembiayaan, perusahaan sekuritas/efek, dan perusahaan asuransi. Informasi faktor kunci sukses untuk industri ini selengkapnya dapat diakses lewat situs http://new.pefindo.com/scrm_lembagakeuangan_index.php?

b. Industri korporasi terdiri dari perusahaan yang bergerak pada industri: otomotif, kimia, minyak kelapa sawit, makanan dan minuman, media, pertambangan, properti, perdagangan eceran, perkapalan, tembakau, dan jalan tol. Informasi faktor kunci sukses untuk industri ini selengakpnya dapat diakses lewat situs http://new.pefindo.com/scrm_korporasi_index.php?

3. Penilaian risiko keuangan. Penilaian risiko keuangan didasarkan pada beberapa hal penting, yaitu:

a. Kebijakan keuangan. Analisis ini mencakup: (1) tinjauan filosofi manajemen, (2) strategi dan kebijakan keuangan terhadap risiko (historis, sekarang, dan proyeksi masa depan), (3) pemeriksaan manajemen atas target keuangan (pertumbuhan, leverage, struktur utang, kebijakan dividen, dan sebagainya), (4) kebijakan lindung nilai, dan kebijakan lain dalam upaya mengurangi risiko keuangan perusahaan secara keseluruhan (sejarah masa lalu versus masa depannya), (5) rekam jejak perusahaan pada saat pemenuhan kewajiban keuangan di masa lalu untuk menentukan tingkat komitmen, kesungguhan, dan konsistensinya untuk membayar kewajiban-kewajibannya secara tepat waktu. 
b. Profitabilitas. Analisis ini mencakup pemeriksaan historis, saat ini, dan proyeksi terhadap profitabilitas, termasuk pertumbuhan, volatilitas, dan kesinambungan profitabilitas melalui naik turunnya siklus bisnis dan siklus ekonomi.

c. Struktur permodalan. Analisis ini mencakup: (1) pemeriksaan sejarah perusahaan untuk saat ini dan proyeksinya atas leverage (total hutang dan nilai bersih hutang dalam hubungannya dengan besar modal, total modal dan arus kas), struktur utang dan komposisinya (Rupiah vs mata uang asing, utang jangka pendek vs hutang jangka panjang, dengan tingkat suku bunga tetap vs suku bunga mengambang), (2) cara pengelolaan kewajiban yang dimiliki perusahaan.

d. Perlindungan arus kas. Analisis ini meliputi kajian dari arus kas perusahaan dan kemampuan untuk memenuhi kewajiban keuangan jangka pendek dan jangka panjang Tingkat kemampuan melayani pembayaran utang diukur oleh rasio pembayaran bunga dan rasio pembayaran utang. Tingkat likuiditas perusahaan di dalam memenuhi kewajiban jangka pendek juga dikaji secara mendalam.

e. Fleksibilitas keuangan. Analisis ini meliputi evaluasi gabungan semua ukuran finansial di atas untuk sampai pada pemahaman yang menyeluruh tentang kesehatan keuangan perusahaan. Analisis tentang faktor-faktor lain yang terkait atau angka angka yang tidak secara khusus ditelaah diatas, seperti klausul perlindungan asuransi, batasan atas perjanjian pinjaman/obligasi atau hubungan dengan induk perusahaan dan bantuan-bantuan juga ditelaah. Penugasan analitis lain yang dibahas adalah evaluasi pilihan yang bisa diambil oleh perusahaan dalam tekanan, termasuk rencana-rencana atas kejadian tidak terduga dan kemampuan serta fleksibilitas untuk berurusan dengan berbagai skenario yang merugikan. Dukungan pemegang saham dan komitmennya juga sangat dipertimbangkan.

Sehubungan dengan kriteria yang ditetapkan PEFINDO, Tandelilin (2010:251) menjelaskan bahwa semakin dekat peringkat obligasi dengan id.AAA berarti semakin bagus peringkatnya dan semakin kecil kemungkinan obligasi akan gagal dalam memenuhi kewajiban membayar bunga dan pokok pinjamannya. Penelitian ini mengikuti Almalia dan Devi (2007), Amrullah (2007), Setyapurnama dan Norpratiwi (2009) dalam penentuan proksi peringkat obligasi yang digunakan. Dalam penelitiannya, Almalia dan Devi (2007), Amrullah (2007), Setyapurnama dan Norpratiwi (2009) tidak menggunakan empat kategori peringkat obligasi, tetapi menyederhanakannya menjadi dua kategori peringkat obligasi, yaitu kategori kelas investasi (investment grade) dan kategori bukan kelas investasi (non investment grade).

\section{Kebijakan Utang dan Peringkat Obligasi}


Kebijakan utang berkaitan dengan kegiatan pendanaan perusahaan. Dana yang diperoleh dapat berasal dari pemilik maupun kreditur (Purwaningsih, 2008). Di satu sisi, penggunaan utang dapat menghemat pajak yang dibayarkan perusahaan (Hanafi, 2004:299), namun di sisi lain, penggunaan utang dapat menyebabkan perusahaan dihadapkan pada risiko gagal bayar (Purwaningsih, 2008). Risiko gagal bayar ini menjadikan perusahaan memiliki peringkat obligasi yang rendah. Beberapa peneliti seperti Kamstra, et al. (2001), Crabtree dan Maher (2005), maupun Amrullah (2006) mengkonfirmasi terdapatnya hubungan yang negatif antara utang dengan kemungkinan penentuan peringkat obligasi. Berdasarkan uraian tersebut, maka dapat dirumuskan hipotesis sebagai berikut.

$\mathrm{H}_{1}$ : Semakin tinggi utang yang digunakan, maka semakin kecil kemungkinan perusahaan penerbit obligasi dikelompokkan pada kategori peringkat investasi (investment grade).

\section{Profitabilitas dan Peringkat Obligasi}

Profitabilitas merupakan kemampuan perusahaan memperoleh laba (Sartono, 2008:122) sekaligus untuk memenuhi kewajibannya (Amrullah, 2007). Tingkat profitabilitas yang tinggi dapat mengindikasikan kemampuan perusahaan untuk going concern (Purwaningsih, 2008). Going concern bagi sebuah perusahaan berarti perusahaan tersebut mampu mempertahankan kegiatan usahanya dalam jangka panjang dan tidak mengalami likuidasi dalam jangka pendek (Santosa dan Wedari, 2007). Semakin tinggi profitabilitas, memungkinkan perusahaaan memperoleh peringkat yang semakin tinggi (Bouzoita dan Young, 1998). Beberapa studi yang dilakukan oleh Kamstra, et al. (2001), Crabtree dan Maher, (2005), Amrullah (2000), maupun Manurung, et al. (2009) mengkonfirmasi bahwa profitabilitas berpengaruh positif terhadap penentuan peringkat obligasi. Berdasarkan uraian tersebut, maka dapat dirumuskan hipotesis sebagai berikut.

$\mathrm{H}_{2}$ : Semakin tinggi profitabilitas maka semakin besar kemungkinan perusahaan penerbit obligasi dikelompokkan pada kategori peringkat investasi (investment grade).

\section{Likuiditas dan Peringkat Obligasi}

Likuiditas merupakan perusahaan menunjukkan kemampuan perusahaan untuk membayar kewajiban finansial jangka pendek tepat pada waktunya. Likuiditas ditunjukkan oleh besar kecilnya aktiva lancar. Aktiva lancar merupakan aktiva yang mudah diubah menjadi kas (Sartono, 2008:116). Peningkatan aktiva lancar tentu saja menyebabkan peningkatan dalam modal kerja bersih sehingga mengurangi tingkat risiko kesulitan keuangan secara teknis (Gitman, 2006:629). Makin tinggi tingkat rasio likuiditas tersebut, maka semakin tinggi posisi likuiditas perusahaan. Tingkat likuiditas menjadi faktor penting dalam penentuan peringkat obligasi (Purwaningsih, 2008). Burton, et al. (2000) yang dikutip 
Almalia dan Devi (2007) menyatakan bahwa tingkat likuidititas yang tinggi menunjukkan kuatnya kondisi keuangan perusahaan sehingga secara finansial mempengaruhi prediksi peringkat obligasi. Hasil penelitian yang dilakukan Almalia dan Devi (2007) maupun Hasnawati dan Dirja (2008) mengkonfirmasi bahwa likuiditas berhubungan positif dengan prediksi peringkat obligasi. Berdasarkan uraian tersebut, maka dapat dirumuskan hipotesis sebagai berikut.

$\mathrm{H}_{3}$ : Semakin tinggi likuiditas, maka semakin besar kemungkinan perusahaan penerbit obligasi dikelompokkan pada kategori kelas investasi (investment grade).

\section{Ukuran Perusahaan dan Peringkat Obligasi}

Ukuran perusahaan terkait dengan besar kecilnya perusahaan. Besar kecilnya perusahaan ini dapat diukur dengan total aktiva yang dimiliki perusahaan (Kamstra, et al. 2001; Crabtree dan Maher, 2005; Almalia dan Devi, 2007; Setyapurnama dan Norpratiwi, 2009). Semakin besar total asset yang dimiliki perusahaan diharapkan semakin mempunyai kemampuan dalam melunasi kewajiban di masa depan (Setyapurnama dan Norpratiwi, 2009) mengingat jumlah aset yang besar dapat dijadikan sebagai jaminan penerbitan obligasi. Dalam konteks ini menurut Tandelilin (2010:247), aset yang biasa dijaminkan biasanya berupa aset riil seperti tanah dan bangunan gudang. ${ }^{5}$ Hasil studi yang dilakukan Ohlson (1980) maupun Shumway (2001) mengkonfirmasi bahwa ukuran berpengaruh negatif terhadap ketidakbangkrutan perusahaan. ${ }^{6}$ Hal ini berarti semakin besar ukuran perusahaan, semakin kecil potensi ketidakbangkrutan yang dialaminya. Dengan demikian, perusahaan yang besar dianggap mempunyai risiko yang lebih kecil dari pada perusahaan kecil (Elton, Gruber, Brown, dan Goetzmann, 2003:150) sehingga perusahaan besar pada umumnya diberikan penilaian peringkat obligasi dalam kategori investasi (Almalia dan Devi, 2007). Beberapa peneliti seperti Kamstra, et al. (2001), maupun Crabtree dan Maher (2005) menemukan bukti empirik yang menyatakan bahwa ukuran perusahaan berhubungan positif terhadap kemungkinan penentuan peringkat obligasi. Berdasarkan uraian tersebut, maka dapat dirumuskan hipotesis sebagai berikut.

$\mathrm{H}_{4}$ : Semakin besar ukuran perusahaan maka semakin besar kemungkinan perusahaan penerbit obligasi dikelompokkan pada kategori peringkat investasi (investment grade).

\footnotetext{
${ }^{5}$ Selain tanah dan bangunan gudang, aset riil ini dapat berwujud pabrik (Husnan, 2009:3), peralatan kantor, maupun kendaraan (Sartono, 2008:191).

${ }^{6}$ Kondisi ini didasari pada argumen Hanafi (2004:656) yang menyatakan bahwa penentuan variabel terikat untuk model kebangkrutan ini merupakan variabel boneka. Variabel boneka ini didefinisikan sebagai 0 untuk perusahaan yang bangkrut dan 1 untuk perusahaan yang tidak bangkrut. Dengan demikian, ketika ukuran bertindak sebagai variabel penjelas dan hasilnya menunjukkan tanda negatif secara signifikan, maka kondisi ini dapat juga diinterpretasikan dalam kalimat lain yang berbunyi semakin besar perusahaan, maka semakin kecil perusahaan mengalami ketidakbangkrutan .
} 


\section{Status Perusahaan dan Peringkat Obligasi}

Selain meminjam uang pada bank (Husnan, 2009:6), salah satu cara perusahaan untuk menambah modal adalah dengan menerbitkan saham (Hartono, 2008:30). Menurut Hartono (2008:30), saham ini dapat dijual dengan berbagai macam cara seperti dijual pada pemegang saham yang ada, dijual pada karyawan lewat ESOP (employee stock ownership plan), menambah saham lewat dividen yang tidak dibagi (dividend reinvestment plan), dijual secara langsung pada pembeli tunggal (biasanya investor institusi) secara privat (private placement), dan ditawarkan pada publik.

Salah satu keuntungan perusahaan menjadi perusahaan publik yaitu memiliki kemudahan dalam meningkatkan modal di masa mendatang (Hartono, 2008:6). Menerbitkan obligasi menjadi lebih mudah bagi perusahaan publik jika dibandingkan dengan perusahaan non-publik. Investor lebih percaya pada reputasi perusahaan publik dari pada perusahaan nonpublik dalam hal membayar bunga obligasi beserta pokoknya di akhir periode. Oleh karena itu, peringkat obligasi yang dimiliki perusahaan publik lebih baik daripada peringkat yang dimiliki perusahaan non publik. Berdasarkan uraian tersebut, maka dapat dirumuskan hipotesis sebagai berikut.

$\mathrm{H}_{5}$ : Perusahaan publik yang menerbitkan obligasi memiliki kemungkinan yang lebih besar untuk dikelompokkan pada kategori peringkat investasi (investment grade) dari pada perusahaan non-publik yang menerbitkan obligasi.

\section{METODE PENELITIAN}

\section{Jenis Penelitian}

Jenis penelitian yang digunakan yaitu penelitian pengujian hipotesis. Menurut Hermawan (2006:18), jenis penelitian ini berusaha untuk menjelaskan sifat dari suatu hubungan atau pengaruh tertentu. Hipotesis yang dipakai dalam penelitian ini yaitu hipotesis kausalitas. Hartono (2004:44) menyatakan hipotesis kausal sebagai hipotesis yang menyatakan hubungan satu variabel yang menyebabkan perubahan variabel lainnya.

\section{Operasionalisasi Variabel Penelitian}

Dalam penelitian ini, variabel terikat yang dimaksudkan yaitu peringkat obligasi. Peringkat obligasi yang dimaksudkan yaitu peringkat obligasi yang dipublikasikan pada Juni 2008. Mengikuti Almalia dan Devi (2007), Amrullah (2007), Hasnawati dan Dirja (2008), Raharja dan Sari (2008), Setyapurnama dan Norpratiwi (2009), peringkat obligasi ini dikategorikan menjadi kelompok investment grade dan kelompok non investment grade. Kelompok investment grade yaitu obligasi dengan peringkat id.AAA, id.AA, id.A, dan id.BBB selanjutnya diberi kode 1 (satu) $(\mathrm{D}=1)$. Kelompok non-investment grade yaitu 
obligasi dengan peringkat id.BB, id.B, id.CCC, id,SD, dan id.D, selanjutnya diberi kode 0 (nol) $(\mathrm{D}=0)$. Adapun variabel penjelas yang digunakan yaitu kebijakan utang, profitabilitas, likuiditas, ukuran perusahaan, dan status perusahaan. Semua proksi variabel penjelas tersebut didasarkan pada kondisi akhir tahun 2007.

(1) Kebijakan utang. Mengikuti Raharja dan Sari (2008), Setyapurnama dan Norpratiwi (2009), maupun Manurung et al. (2009), kebijakan utang diproksi dengan menggunakan rasio utang terhadap modal (debt equity ratio/DER). Menurut Van Horne dan Wachowicz (1995:130), rasio ini merupakan perbandingan total utang dengan ekuitas pemegang saham pada akhir tahun.

(2) Profitabilitas. Mengikuti Kamstra, et al., (2001); Crabtree dan Maher, (2005); Almalia dan Devi (2007), Amrullah (2007), Manurung, et al., (2009), profitabilitas diproksi dengan return on asset (ROA). Menurut Hanafi (2004:42), rasio ini merupakan perbandingan antara laba setelah bunga dan pajak dengan total aktiva yang dimiliki perusahaan pada akhir tahun.

(3) Likuiditas. Mengikuti Almalia dan Devi (2007), Hasnawati dan Dirja (2008), maupun Manurung, et al. (2009), likuiditas diproksi dengan menggunakan rasio lancar/current ratio (CR). Menurut Hanafi (2004:37), rasio ini mengukur kemampuan perusahaan memenuhi utang jangka pendeknya dengan menggunakan aktiva lancar dan didefinisikan sebagai perbandingan antara aktiva lancar dengan utang lancar yang dimiliki perusahaan pada akhir tahun.

(4) Ukuran perusahaan. Mengikuti Kamstra, et al. (2001), Crabtree dan Maher (2005), Almalia dan Devi (2007), maupun Setyapurnama dan Norpratiwi (2009), ukuran perusahaan diproksi dengan menggunakan total aktiva/total asset (TA).

(5) Status perusahaan (D_STAT). Status perusahaan diproksi dengan menggunakan variabel boneka (dummy variable). D_STAT $=1$ jika perusahaan penerbit obligasi merupakan perusahaan publik. D_STAT $=0$ jika perusahaan penerbit obligasi bukan merupakan perusahaan publik.

\section{Data dan Sampel}

Unit analisis yang digunakan yaitu perusahaan penerbit obligasi. Sampel yang digunakan dalam penelitian ini yaitu semua perusahaan yang masih tercatat memiliki obligasi sampai pada Juni 2008. Karena tidak semua perusahaan memiliki peringkat obligasi, maka kriteria pemilihan sampel mengikuti beberapa prosedur yang tersaji pada Tabel 4. Berdasarkan kriteria tersebut, terdapat 102 perusahaan yang dijadikan sebagai sampel. Keseratus dua perusahaan penerbit obligasi tersebut dikategorikan pada dua kategori 
peringkat obligasi, yaitu obligasi dengan peringkat kelas investasi sebanyak 86 perusahaan dan obligasi dengan peringkat kelas bukan investasi sebanyak 16 perusahaan. Adapun nama perusahaan yang dimaksudkan dapat dilihat pada Lampiran 1. Data perusahaan yang dijadikan sampel penelitian ini diperoleh dari Indonesian Bond Market Directory (IBMD) 2008 yang tersedia di Pojok Bursa Efek Indonesia Sinar Mas Universitas Kristen Maranatha. IBMD tersebut memuat data rasio keuangan dan peringkat dari perusahaan yang menerbitkan obligasi.

Tabel 4. Prosedur Pemilihan Sampel

\begin{tabular}{|l|r|}
\hline \multicolumn{1}{|c|}{ Kriteria } & Jumlah \\
\hline Perusahaan penerbit obligasi sampai tahun 2008 & 105 \\
\hline Perusahaan penerbit obligasi tanpa peringkat obligasi & $(3)$ \\
\hline Perusahaan penerbit obligasi dengan peringkat obligasi & 102 \\
\hline
\end{tabular}

\section{HASIL DAN ANALISIS PEMBAHASAN}

\section{Deskripsi Statistika}

Peringkat obligasi (RATING) diproksi dengan variabel boneka dua kategori, yaitu 0 (nol) dan 1 (satu). Kategori 0 (nol) merupakan simbol untuk perusahaan yang tergabung pada kelompok perusahaan penerbit obligasi dengan peringkat investasi (investment grade), sedangkan kategori 1 (satu) merupakan simbol untuk perusahaan penerbit obligasi dengan peringkat bukan investasi (non investment grade). Baik rasio utang terhadap ekuitas (DER) maupun rasio lancar (CR) keduanya dinyatakan dalam nilai desimal. Nilai pengembalian atas total aktiva (ROA) dinyatakan dalam satuan persen. Ukuran perusahaan diproksi dengan total aktiva yang dinyatakan dalam satuan numerik. Status perusahaan (D_STAT) diproksi dengan variabel boneka 2 kategori, yaitu 0 (nol) dan 1 (satu). Kategori 0 (nol) merupakan simbol untuk perusahaan yang tergabung pada kelompok perusahaan tertutup, sedangkan kategori 1 (satu) merupakan simbol untuk perusahaan yang tergabung pada kelompok perusahaan terbuka. Selengkapnya, ukaran statistik deskripsi atas keenam variabel penelitian dapat dilihat pada Tabel 5.

Tabel 5. Statistik Deskriptif Variabel Penelitian

\begin{tabular}{|c|c|c|c|c|c|}
\hline Variabel & $\mathrm{N}$ & Minimum & Maksimum & Rata-Rata & Standar Deviasi \\
\hline RATING & 102 & 0 & 1 & 0,84 & 0,365 \\
\hline DER & 102 & 0,00 & 16,56 & 3,9385 & 3,84661 \\
\hline ROA & 102 & $-8,88$ & 23,11 & 4,1508 & 4,67880 \\
\hline CR & 102 & 0,09170 & 13,74686 & 1,8703517 & 1,87829191 \\
\hline TA & 102 & 1732 & 273479935 & 15355959,97 & 39103270,636 \\
\hline D_STAT & 102 & 0,00 & 1,00 & 0,5686 & 0,49771 \\
\hline
\end{tabular}

Sumber: Hasil Pengolahan Data SPSS 12.0 


\section{Model Penelitian Yang Digunakan}

Dalam penelitian ini model prediksi keanggotaan kelompok yang digunakan yaitu model regresi logistik. Model ini digunakan mengingat karakteristik data empirik yang digunakan semuanya memenuhi uji asumsi model ini. Beberapa uji asumsi model regresi logistik yaitu distribusi data variabel bebas yang tidak normal (Ghozali, 2007:225), varians antar kelompok untuk setiap variabel bebas tidak homogen (Hair, et al., 1998:314), tidak liniernya hubungan antara probabilitas $\left(\mathrm{p}_{\mathrm{i}}\right)$ dengan variabel bebas (Ghozali, 2007:228), lolos uji kesesuaian model dengan data yang digunakan (Ghozali, 2007:232). Berikut ini merupakan pembuktian secara statistiknya.

\section{A. Uji Normalitas.}

Pada model regresi logistik, tidak perlu dipenuhi asumsi normalitas data pada variabel bebasnya (Ghozali, 2007:225). Untuk memastikan data pada variabel bebas tidak berdistribusi normal, maka uji normalitas Kolmogorov-Smirnov terhadap masing-masing-masing variabel bebas perlu dilakukan. Adapun prosedur pengujian normalitas menurut Ghozali (2007:30) yaitu sebagai berikut.

1. Merumuskan hipotesis nol $\left(\mathrm{H}_{0}\right)$ dan hipotesis alternatif $(\mathrm{Ha})$ sebagai berikut.

$\mathrm{H}_{0}$ : Data terdistribusi secara normal.

Ha: Data tidak terdistribusi secara normal.

2. Menetapkan kriteria pengujian hipotesis dengan menggunakan tingkat signikansi $(\alpha)$ sebesar 0,05. Mengikuti Ghozali (2007:115), jika nilai Asymp. Sig. (2-tailed) lebih kecil dari pada tingkat signikansi $(\alpha)$ sebesar 0,05 maka $\mathrm{H}_{0}$ ditolak dan sebaliknya.

- Ditolaknya $\mathrm{H}_{0}$ berarti data tidak terdistribusi secara normal. Menurut Ghozali (2007:225), tidak dipenuhinya asumsi normalitas ini mengindikasikan model regresi logistik ini layak untuk digunakan.

- Ditolaknya Ha berarti data terdistribusi secara normal. Dipenuhinya asumsi normalitas ini mengindikasikan model regresi logistik ini tidak layak digunakan. Dengan demikian, model yang layak direkomendasikan yaitu model regresi probit (Gujarati, 2007:615).

Pada Tabel 6, terlihat bahwa semua variabel bebas (DER, ROA, CR, TA, dan D_STAT) signifikan pada tingkat signikansi $(\alpha)$ sebesar 0,05 . Hal ini menunjukkan bahwa setiap variabel penjelas tidak berdistribusi normal. Tidak terpenuhinya asumsi normalitas ini merekomendasikan supaya model regresi logistiklah yang digunakan. 
Tabel 6. Hasil Uji Normalitas dengan Kolmogorov Smirnov

\begin{tabular}{|l|l|r|r|r|r|r|}
\hline \multicolumn{2}{|c|}{ Independent Variable } & \multicolumn{1}{c|}{ DER } & \multicolumn{1}{c|}{ ROA } & CR & TA & D_STAT \\
\hline $\mathrm{N}$ & 102 & 102 & 102 & 102 & 102 \\
\hline \multirow{2}{*}{$\begin{array}{l}\text { Normal } \\
\text { Parameters }\end{array}$} & Mean & 3,9385 & 4,1508 & 1,8703517 & 15355959,97 & 0,5686 \\
\cline { 2 - 7 } & $\begin{array}{l}\text { Std. } \\
\text { Deviation }\end{array}$ & 3,84661 & 4,67880 & 1,87829191 & 39103270,636 & 0,49771 \\
\hline $\begin{array}{l}\text { Most } \\
\text { Extreme } \\
\text { Differences }\end{array}$ & Absolute & 0,198 & 0,183 & 0,227 & 0,347 & 0,376 \\
\cline { 2 - 7 } & Positive & 0,198 & 0,183 & 0,227 & 0,304 & 0,305 \\
\cline { 2 - 7 } & Negative & $-0,164$ & $-0,151$ & $-0,208$ & $-0,347$ & $-0,376$ \\
\hline Kolmogorov-Smirnov Z & 2,004 & 1,852 & 2,296 & 3,507 & 3,793 \\
\hline Asymp. Sig. (2-tailed) & 0,001 & 0,002 & 0,000 & 0,000 & 0,000 \\
\hline
\end{tabular}

Sumber: Hasil Pengolahaan Data SPSS 12.0

B. Uji Homogenitas Varians.

Pada model regresi logistik, varians untuk setiap variabel bebas antarkelompok seharusnya tidak bersifat homogen (Hair, et al., 1998:314). Untuk memastikan ketidakhomogenan data, maka digunakanlah prosedur uji homogenitas data. Berikut ini merupakan prosedur pengujian homogenitas data dengan statistik Box's M (Santoso, 2006: 116).

1. Merumuskan hipotesis nol $\left(\mathrm{H}_{0}\right)$ dan hipotesis alternatif $(\mathrm{Ha})$ sebagai berikut.

$\mathrm{H}_{0}$ : Matriks kelompok varian relatif sama.

Ha: Matriks kelompok varian berbeda.

2. Mengambil keputusan berdasarkan hasil pengujian statistik Box's M. Jika nilai Sig. F

(Box’s M) lebih besar dari 0,05 maka $\mathrm{H}_{0}$ diterima, dan sebaliknya.

Tabel 7. Hasil Uji Homogenitas Varians

\begin{tabular}{|c|c|c|c|c|}
\hline $\begin{array}{c}\text { Box's M } \\
\text { Statistics }\end{array}$ & F Approx. & $\mathrm{df}_{1}$ & $\mathrm{df}_{2}$ & Sig \\
\hline 44,847 & 2,610 & 15 & 2777,845 & 0,001 \\
\hline
\end{tabular}

Terlihat pada Tabel 7, nilai signifikansi F dari nilai Box’s M sebesar 0,001. Nilai ini lebih kecil dari pada $\alpha$ sebesar 0,05. Dengan demikian, Ha diterima. Hal ini berarti matriks kelompok varians berbeda atau bersifat tidak homogen. Dipenuhinya asumsi ketidakhomogenan varian untuk setiap variabel bebas antar kelompok mendukung digunakannya model regresi logistik dalam penelitian ini.

\section{Uji Linieritas}

Linieritas ialah keadaan dimana hubungan antara variabel dependen dengan variabel independen bersifat linier, baik itu positif maupun negatif (Santoso, 2009:192). Dalam model regresi logistik, linieritas yang dimaksud mengacu pada hubungan nilai prediksi probabilitas 
$\left(\mathrm{p}_{\mathrm{i}}\right)$ sebagai variabel terikat dengan DER, ROA, CR, TA, dan D_STAT sebagai variabel bebasnya. Menurut Ghozali (2007:228), dalam model regresi logistik, hubungan antara probabilitas dengan variabel bebas tidak linier. Untuk menguji terdapatnya ketidaklinieran hubungan tersebut maka Ghozali (2007:118) menyarankan untuk menggunakan uji Ramsey RESET. Berikut ini merupakan langkah-langkah prosedur pengujiannya.

1. Merumuskan hipotesis nol $\left(\mathrm{H}_{0}\right)$ dan hipotesis alternatif $(\mathrm{Ha})$.

$\mathrm{H}_{0}$ : Terjadi hubungan linier antara variabel bebas dengan nilai probabilitas $\left(\mathrm{p}_{\mathrm{i}}\right)$.

Ha: Tidak terjadi hubungan linier antara variabel bebas dengan nilai probabilitas $\left(\mathrm{p}_{\mathrm{i}}\right)$.

2. Mencari nilai kesesuaian (fitted value) (FITTED) dari variabel terikat pada model regresi. Prosedur ini digunakan dengan metode OLS (ordinary least square).

3. Mengkuadratkan nilai kesesuaian $\left(\right.$ FITTED $\left.^{\wedge} 2\right)$ dan memasukkan nilai ini sebagai variabel bebas dalam model regresi bersama-sama dengan variabel DER, ROA, CR, TA, dan D_STAT.

4. Menjalankan prosedur estimasi regresi berganda OLS dengan menggunakan nilai estimasi probabilitas sebagai variabel terikatnya dan FITTED $^{\wedge} 2$, DER, ROA, CR, TA dan D_STAT sebagai variabel bebasnya. Adapun hasil estimasi model pengujiannya dapat dilihat pada Tabel 8 .

\section{Tabel 8. Hasil Uji Linieritas dengan Ramsey RESET}

\begin{tabular}{|c|c|c|c|c|}
\hline $\begin{array}{l}\text { F-statistic } \\
\text { Log likelihood ratio }\end{array}$ & $\begin{array}{l}1924,820 \\
311,8024\end{array}$ & \multicolumn{2}{|l|}{$\begin{array}{l}\text { Probability } \\
\text { Probability }\end{array}$} & $\begin{array}{l}0,000000 \\
0,000000\end{array}$ \\
\hline \multicolumn{5}{|c|}{$\begin{array}{l}\text { Test Equation: } \\
\text { Dependent Variable: RATINGF } \\
\text { Method: Least Squares } \\
\text { Date: } 01 / 29 / 10 \text { Time: } 01: 16 \\
\text { Sample: } 1102 \\
\text { Included observations: } 102 \\
\end{array}$} \\
\hline Variable & Coefficient & Std. Error & t-Statistic & Prob. \\
\hline $\mathrm{C}$ & 1,208368 & 0,015132 & 79,85572 & 0,0000 \\
\hline DER & 0,113976 & 0,002177 & 52,36022 & 0,0000 \\
\hline ROA & 0,091540 & 0,001746 & 52,42304 & 0,0000 \\
\hline $\mathrm{CR}$ & 0,270471 & 0,005184 & 52,17174 & 0,0000 \\
\hline TA & $6,34 \mathrm{E}-09$ & $1,24 \mathrm{E}-10$ & 51,23473 & 0,0000 \\
\hline D_STAT & 0,498228 & 0,009627 & 51,75136 & 0,0000 \\
\hline FITTED ${ }^{\wedge} 2$ & $-2,835925$ & 0,064640 & $-43,87277$ & 0,0000 \\
\hline
\end{tabular}

Sumber: Hasil Pengolahan Data EViews 5.0

5. Mengambil kesimpulan statistik, yaitu dengan membandingkan nilai F-statistik dari uji Ramsey RESET dengan nilai $\mathrm{F}$ tabel dengan tingkat signifikansi $(\alpha)$ sebesar 5\% dan 
derajat kebebasan (d.k.1 dan d.k.2). Derajat kebebasan pertama (d.k.1) yaitu sebesar k, derajat kebebasan kedua (d.k.2) yaitu sebesar n-k-1.

- Jika nilai $\mathrm{F}$ statistik $>\mathrm{F}$ tabel, maka $\mathrm{H}_{0}$ ditolak.

- Jika nilai $\mathrm{F}$ statistik $\leq \mathrm{F}$ tabel, maka $\mathrm{H}_{0}$ tidak ditolak.

Terlihat pada Tabel 8, nilai F statistik sebesar 1924,820. Selanjutnya nilai ini dibandingkan dengan $\mathrm{F}$ tabel $\left(\mathrm{df}_{1}=6, \mathrm{df}_{2}=102-6-1=95\right)$ sebesar 2,195547646 . Ternyata nilai F statistik $>$ nilai $\mathrm{F}$ tabel. Dengan demikian maka $\mathrm{H}_{0}$ ditolak. Ini berarti tidak terjadi hubungan linier antara variabel bebas dengan nilai probabilitas $\left(\mathrm{p}_{\mathrm{i}}\right)$. Hasil ini mendukung asumsi model regresi logistik.

D. Penilaian kesesuaian model (model fit test).

Terdapat 3 (tiga) cara penilaian kesesuaian model regresi logistik dengan data yang ada. Ketiga cara tersebut menurut Ghozali (2007:237-238) yaitu dengan melihat penurunan nilai statistik -2 Likelihood, kenaikan nilai $\mathrm{R}^{2} \mathrm{Cox}$ dan Snell/nilai $\mathrm{R}^{2}$ Nagelkerke, dan nilai probabilitas dari statistik Hosmer-Lemeshow.

1. Penurunan nilai -2Likelihood.

Penurunan nilai -2 Likelihood yang dimaksudkan adalah penurunan nilai sebelum dan setelah adanya variabel bebas dalam model. Selanjutnya selisih nilai -2 Log Likehood ini dibandingkan dengan nilai $\chi^{2}$ tabel dengan selisih derajat kebebasan/degree of freedom (df). Derajat kebebasan yang dimaksudkan yaitu derajat kebebasan setelah penambahan variabel bebas $\left(\mathrm{df}_{2}\right)^{7}$ dan derajat kebebasan sebelum adanya penambahan variabel bebas $\left(\mathrm{df}_{1}\right)^{8}$. Apabila nilai selisih statistik -2 Log Likelihood lebih besar daripada $\chi^{2}$ tabel, maka dapat dikatakan penurunan nilai statistik -2 Log Likehood signifikan, artinya penambahan variabel bebas ke dalam model memperbaiki kesesuaian model (Ghozali, 2007:237).

Tabel 9. Hasil Uji Signifikansi Penurunan Nilai -2 Log Likelihood

\begin{tabular}{|c|c|c|c|c|}
\hline Langkah & $\begin{array}{c}\text { Nilai-2 Log } \\
\text { Likelihood }\end{array}$ & $\begin{array}{c}\text { Besarnya Penurunan } \\
\text { Nilai -2 Log } \\
\text { Likelihood }\end{array}$ & $\begin{array}{c}\chi^{2} \text { tabel } \\
(\alpha=5 \%, \\
\Delta \mathrm{df}=4)\end{array}$ & Kesimpulan \\
\hline 0 & 88,624 & 10,057 & 9,487729 & $\begin{array}{c}\text { Penurunan nilai -2Log } \\
\text { Likehood signifikan }\end{array}$ \\
\hline 1 & 78,567 & &
\end{tabular}

Sumber: Hasil Pengolahan Data SPSS 12.0 dan Microsoft Excel 2007

\footnotetext{
${ }^{7}$ Formulasi rumus untuk mencari derajat kebebasan setelah penambahan variabel bebas $\left(\mathrm{df}_{2}\right)$ yaitu sebesar $n-k$, dimana $\mathrm{n}$ menunjukkan banyaknya observasi, $\mathrm{k}$ menunjukkan banyaknya variabel bebas. Dengan demikian, besarnya $\mathrm{df}_{2}=102-5=97$.

${ }^{8}$ Formulasi rumus untuk mencari derajat kebebasan sebelum penambahan variabel bebas $\left(\mathrm{df}_{1}\right)$ yaitu sebesar $\mathrm{n}-\mathrm{k}$, dimana $\mathrm{n}$ menunjukkan banyaknya observasi, dan $\mathrm{k}$ menunjukkan terdapatnya sebuah intersep. Dengan demikian, besarnya $\mathrm{df}=102-1=101$.
} 
Selengkapnya, hasil uji signifikansi terhadap penurunan nilai -2 Log Likehood dapat dilihat pada Tabel 9. Pada tabel tersebut, terlihat nilai $\chi^{2}$ tabel $(\alpha=5 \%, \Delta \mathrm{df}=101-97=4)$ sebesar 7,814728, sedangkan besarnya penurunan nilai -2 Log Likelihood sebesar 19,013. Sesuai dengan yang dikemukakan Ghozali (2007:237), karena penurunan nilai -2 Log Likelihood lebih besar daripada $\chi^{2}$ tabel, maka dapat dikatakan penurunan nilai statistik -2 Log Likehood signifikan, artinya penambahan variabel bebas ke dalam model memperbaiki kesesuaian model.

2. Kenaikan nilai $\mathrm{R}^{2}$ Cox dan Snell/nilai $\mathrm{R}^{2}$ Nagelkerke.

Nilai $\mathrm{R}^{2}$ Cox dan Snell yang semakin tinggi menunjukkan semakin besar tingkat kesesuaian model. Namun, nilai ini memiliki keterbatasan, yaitu tidak dapat mencapai nilai maksimum sebesar 1. Untuk alasan inilah, Nagelkerke memodifikasi nilai tersebut. Modifikasi tersebut menghasilkan nilai $\mathrm{R}^{2}$ Nagelkerke (Hair, et al., 1988:318). Nilai $\mathrm{R}^{2}$ Nagelkerke dapat diinterpretasikan seperti nilai $\mathrm{R}^{2}$ pada model regresi berganda (Ghozali, 2007:238).

Tabel 10. Nilai $\mathbf{R}^{2}$ Cox dan Snell, Nilai $\mathbf{R}^{2}$ Nagelkerke dalam Menjelaskan Kekuatan Model Regresi Logistik

\begin{tabular}{|c|l|c|c|}
\hline Tahap & \multicolumn{1}{|c|}{$\begin{array}{c}\text { Variabel Bebas } \\
\text { Yang Digunakan }\end{array}$} & $\begin{array}{c}\text { Nilai R }^{2} \\
\text { Cox dan Snell }\end{array}$ & $\begin{array}{c}\text { Nilai R }^{2} \\
\text { Nagelkerke }\end{array}$ \\
\hline I & DER & 0,005 & 0,009 \\
\hline II & DER, ROA & 0,026 & 0,045 \\
\hline III & DER, ROA, dan CR & 0,062 & 0,107 \\
\hline IV & DER, ROA, CR, dan TA & 0,082 & 0,141 \\
\hline V & DER, ROA, CR, TA, dan D_STAT & 0,094 & 0,162 \\
\hline
\end{tabular}

Sumber: Hasil Pengolahan Data SPSS 12.0

Terlihat pada Tabel 10, nilai Nilai $\mathrm{R}^{2}$ Cox dan Snell maupun nilai $\mathrm{R}^{2}$ Nagelkerke mengalami kenaikan ketika satu per satu variabel penjelas yang digunakan dimasukkan dalam model regresi logistik mulai dari variabel FCFTAR pada tahap I, selanjutnya variabel DER dimasukkan pada tahap II bersama dengan variabel FCTAR. Pada tahap III, variabel ROA dimasukkan ke dalam model bersamaan dengan variabel penjelas yang ada pada model tahap II. Kondisi ini berlangsung sampai seluruh variabel penjelas dimasukkan dalam model regresi logistik, yaitu pada Tahap V. Kondisi ini dapat juga diartikan bahwa setiap variabel penjelas memiliki tambahan kontribusi dalam menjelaskan kemampuan model regresi logistik.

3. Nilai statistik Hosmer-Lemeshow (H-L)

Nilai statistik H-L ini dapat digunakan untuk menilai tingkat kesesuaian model dengan menggunakan kriteria pengujian sebagai berikut (Ghozali, 2007:238). 
- Jika nilai probabilitas dari statistik H-L lebih kecil dari $\alpha$ sebesar 5\% (nilai statistik H-L signifikan), maka model logistik tidak sesuai dengan data yang ada.

- Jika nilai probabilitas dari statistik H-L lebih besar dari $\alpha$ sebesar 5\% (nilai statistik H-L tidak signifikan), maka model logistik sesuai dengan data yang ada.

Pada Tabel 11, terlihat hasil uji Hosmer dan Lemeshow masih menunjukkan hasil yang tidak signifikan. Disebut tidak signifikan karena nilai probabilitas dari statistik H-L lebih besar dari tingkat signifikansi $(\alpha)$ sebesar 5\%. Hal ini berarti model logistik sesuai dengan data yang tersedia.

Tabel 11. Hosmer dan Lemeshow Test

\begin{tabular}{|c|c|c|}
\hline Chi-square & df & Sig. \\
\hline 5,864 & 8 & 0,662 \\
\hline
\end{tabular}

Sumber: Hasil Pengolahan Data SPSS 12.0

Model regresi logistik berguna untuk menguji apakah probabilitas terjadinya variabel terikat dapat diprediksi dengan menggunakan variabel bebasnya (Ghozali, 2007:225). Variabel terikat pada model ini merupakan variabel yang memiliki skala non metrik sedangkan variabel bebasnya dapat berbentuk skala metrik ${ }^{9}$ maupun skala non metrik ${ }^{10}$ (Hartono, 2004:141). Dalam penelitian ini, variabel dengan skala metrik yang digunakan yaitu DER, ROA, CR, TA, sedangkan variabel non metriknya yaitu D_STAT. Adapun hasil estimasi model regresi logistik yang digunakan dapat dilihat Tabel 12.

Tabel 12. Hasil Estimasi Model Regresi Logistik

\begin{tabular}{|c|c|c|c|c|}
\hline Variabel & B & S.E. & Wald & Sig. \\
\hline Constant & $-0,763$ & 0,891 & 0,734 & 0,392 \\
\hline DER & 0,179 & 0,112 & 2,520 & 0,112 \\
\hline ROA & 0,133 & 0,079 & 2,805 & 0,094 \\
\hline CR & 0,496 & 0,315 & 2,473 & 0,116 \\
\hline TA & 0,000 & 0,000 & 0,722 & 0,395 \\
\hline D_STAT & 0,706 & 0,606 & 1,357 & 0,244 \\
\hline
\end{tabular}

Sumber: Hasil Pengolahan Data SPSS 12.0

\section{Pengujian Hipotesis dan Pembahasan}

Semua hipotesis dalam penelitian ini diuji dengan menggunakan uji Wald. Uji ini dilakukan dengan membandingkan nilai probabilitas ( $p$-value) statistik Wald dengan tingkat signifikansi $(\alpha)$ sebesar 5\%. Meski demikian, $\alpha$ dapat diperlonggar sampai 10\%. Hal ini dilandasi oleh pendapat Hartono (2008:362) yang menyatakan bahwa tingkat keyakinan yang

\footnotetext{
${ }^{9}$ Menurut Ghozali (2007:5), skala metrik dapat berbentuk skala interval maupun skala rasio.

${ }^{10}$ Skala non metrik dapat berbentuk skala nominal maupun skala ordinal (Ghozali, 2007:4).
} 
paling rendah untuk dapat menolak hipotesis nol yaitu dengan tingkat keyakinan 90\%. Karena menggunakan $\alpha$ sebesar 10\% maka, kriteria pengujiannya yaitu jika nilai probabilitas statistik Wald $<10 \%$, maka hipotesis penelitian tidak ditolak, dan sebaliknya jika nilai probabilitas dari statistik Wald $\geq 10 \%$.

Hipotesis pertama menyatakan semakin tinggi utang yang digunakan, maka semakin kecil kemungkinan perusahaan penerbit obligasi dikelompokkan pada kategori peringkat investasi (investment grade). Terlihat pada Tabel 12, nilai probabilitas statistik Wald atas variabel DER sebagai proksi dari kebijakan utang sebesar 0,112. Karena nilai probabilitas lebih besar dari $\alpha$ sebesar $10 \%$ maka $\mathrm{H}_{1}$ ditolak. Kondisi ini menunjukkan bahwa kebijakan utang tidak berpengaruh terhadap kemungkinan penentuan peringkat obligasi. Dengan demikian, hasil temuan penelitian ini konsisten dengan Setyapurnama dan Norpratiwi (2009) maupun Manurung, et al. (2009). Tidak dapatnya kebijakan utang dalam memprediksi kemungkinan penentuan peringkat obligasi disebabkan oleh terdapatnya prinsip pertukaran antara risiko dan manfaat dari digunakannya utang. Di satu sisi, peningkatan utang dapat meningkatkan potensi kerugian sekaligus kebangkrutan yang tidak dapat dihindari (Hanafi, 2004:310). Namun di sisi lain, peningkatan utang juga membawa manfaat berupa penghematan pajak (Hanafi, 2004:299).Oleh karena itu, peneliti berargumen bahwa kebijakan utang menjadi tidak relevan karena adanya efek subtitusi dari potensi kerugian/kebangkrutan dengan penghematan pajak. Karena kebijakan utang ini tidak relevan, maka tentu saja kebijakan utang ini tidak dapat digunakan dalam memprediksi kemungkinan penentuan peringkat obligasi.

Hipotesis kedua menyatakan semakin tinggi profitabilitas maka semakin besar kemungkinan perusahaan penerbit obligasi dikelompokkan pada kategori peringkat investasi (investment grade). Terlihat pada Tabel 12, nilai probabilitas statistik Wald atas variabel ROA sebagai proksi dari profitabilitas sebesar 0,094 dan menunjukkan ekspektasi tanda yang positif. Karena nilai probabilitas lebih kecil dari $\alpha$ sebesar $10 \%$ maka $\mathrm{H}_{2}$ tidak ditolak. Kondisi ini menunjukkan bahwa profitabilitas dapat memprediksi kemungkinan penentuan peringkat obligasi. Dengan demikian, hasil temuan penelitian ini konsisten dengan Kamstra, et al. (2001), Crabtree dan Maher, (2005), Amrullah (2000), maupun Manurung, et al. (2009). Hasil ini mengkonfirmasi pernyataaan Purwaningsih (2008) yang menyatakan profitabilitas yang tinggi mengindikasikan perusahaan untuk melangsungkan kegiatan usahanya/going concern. Selain menunjukkan kemampuan untuk melangsungkan hidup (going concern), laba juga merupakan alat penarik sumber pendanaan eksternal (Gitman, 2006). Dengan adanya laba yang tinggi, pemberi pinjaman lebih dapat diyakinkan bahwa perusahaan memiliki 
kemampuan membayar bunga secara teratur pada mereka (Wijaya dan Hadianto, 2008). Hal ini tentu saja memperkecil risiko gagal bayar sehingga peringkat perusahaan penerbit obligasi menjadi semakin baik atau dapat terklasifikasi pada kategori kelas investasi.

Hipotesis ketiga menyatakan semakin tinggi likuiditas, maka semakin besar kemungkinan perusahaan penerbit obligasi dikelompokkan pada kategori kelas investasi (investment grade). Terlihat pada Tabel 12, nilai probabilitas statistik Wald atas variabel CR sebagai proksi dari likuiditas sebesar 0,116. Karena nilai probabilitas lebih besar dari $\alpha$ sebesar $10 \%$ maka $\mathrm{H}_{3}$ ditolak. Kondisi ini menunjukkan bahwa likuiditas tidak berpengaruh terhadap kemungkinan penentuan peringkat obligasi. Dengan demikian, hasil penelitian ini tidak konsisten dengan hasil temuan Almalia dan Devi (2007), Hasnawati dan Dirja (2008), maupun Manurung, et al. (2009). Tidak signifikannya hasil penelitian ini dengan yang dihipotesiskan disebabkan karena secara statistik tidak terjadi perbedaan rasio lancar antara perusahaan penerbit obligasi yang memiliki peringkat kelas investasi dengan perusahaan penerbit obligasi yang memiliki peringkat investasi. ${ }^{11}$ Secara teoritis, perusahaan yang cenderung berorientasi pada profitabilitas, tentu saja tidak begitu memperhatikan likuiditas. Sesuai dengan konsep pertukaran yang dipaparkan Gitman (2006:629), peneliti beranggapan bahwa perusahaan yang mengutamakan profitabilitas akan cenderung banyak memiliki aktiva tetap. Bertambahnya aktiva tetap ini menyebabkan berkurangnya aktiva lancar dalam perusahaan. Dengan demikian, jika porsinya berkurang tentu saja perhatian pihak manajemen dalam mengelola likuiditas ini tidak begitu efektif jika dibandingkan dengan perusahaan yang memiliki tingkat likuiditas yang lebih tinggi.

Hipotesis keempat menyatakan semakin tinggi ukuran perusahaan, maka semakin besar kemungkinan perusahaan penerbit obligasi dikelompokkan pada kategori peringkat investasi (investment grade). Terlihat pada Tabel 12, nilai probabilitas statistik Wald atas variabel TA sebagai proksi dari ukuran perusahaaan sebesar 0,395. Karena nilai probabilitas lebih besar dari $\alpha$ sebesar $10 \%$ maka $\mathrm{H}_{4}$ ditolak. Kondisi ini menunjukkan bahwa ukuran perusahaan tidak berpengaruh terhadap kemungkinan penentuan peringkat obligasi. Dengan demikian, hasil temuan penelitian ini konsisten dengan Almalia dan Devi (2007) maupun Setyapurnama dan Norpratiwi (2009). Tidak signifikannya hasil pengujian hipotesis keempat

\footnotetext{
${ }^{11}$ Hal ini terjadi karena dalam konteks analisis regresi logistik, jika sebuah variabel penjelas berhasil untuk membedakan kategori kelompok secara signifikan, variabel penjelas itulah yang signifikan dalam menjelaskan kategori pengelompokan variabel terikat. Dalam konteks ini, variabel penjelas yang dimaksudkan yaitu likuiditas sedangkan kategori variabel terikat yaitu peringkat obligasi. Dengan demikian, jika likuiditas tidak dapat membedakan kategori perusahaan penerbit obligasi maka likuiditas ini tidak berpengaruh secara signifikan terhadap peringkat obligasi.
} 
ini dapat dijelaskan lewat subtitusi antara penjaminan aktiva (Tandelilin, 2010:247) dengan kemungkinan terjadinya kegagalan pendanaan proyek dengan menggunakan utang (Sugiarto, 2009:59). Menurut konsep penjaminan aktiva, perusahaan besar memiliki peringkat obligasi yang lebih baik dari pada perusahaan kecil karena mempunyai kemampuan dalam menjaminkan aktivanya sehingga berdampak pada rendahnya risiko yang dihadapi (Tandelilin, 2010:247). Namun di sisi lain, perusahaan yang berskala besar juga dapat memiliki korelasi terhadap tingkat risiko kegagalan/kebangkrutan sehingga dapat mempengaruhi peringkat obligasi (Almalia dan Devi, 2007). Risiko kegagalan yang dimaksud terjadi ketika investasi perluasan usaha (ekspansi) yang didanai oleh utang mengalami kegagalan (Sugianto, 2009:59). ${ }^{12}$

Hipotesis kelima menyatakan perusahaan publik yang menerbitkan obligasi memiliki kemungkinan yang lebih besar untuk dikelompokkan pada kategori peringkat investasi (investment grade) dari pada perusahaan non-publik yang menerbitkan obligasi. Terlihat pada Tabel 12, nilai probabilitas statistik Wald atas variabel D_STAT sebagai proksi dari status

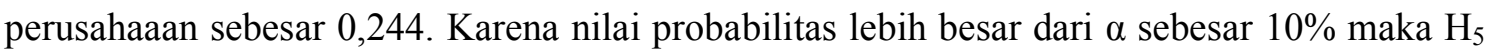
ditolak. Kondisi ini menunjukkan bahwa status perusahaan tidak berpengaruh terhadap kemungkinan penentuan peringkat obligasi. Hasil pengujian ini mengindikasikan bahwa lembaga pemeringkatan obligasi perusahaan tetap konsisten dalam menjalankan rambu-rambu dalam menetapkan kriteria peringkat obligasi tanpa melihat perbedaan kategori perusahaan penerbit obligasi, baik sebagai perusahaan publik maupun sebagai perusahaan non publik. Menurut Pratomo dan Nugraha (2009:161), Pefindo sebagai lembaga pemeringkatan lebih mempertimbangkan beberapa kriteria seperti: (1) kemungkinan pelunasan pembayaran: penilaian atas kapasitas dan kemampuan obligor dalam memenuhi kewajiban finansialnya sesuai dengan yang dijanjikan, (2) perlindungan yang diberikan maupun posisi klaim dari pemegang utang tersebut jika terjadi pembubaran perseroan dan likuidasi.

\section{Matriks Klasifikasi: Pengukur Akurasi Klasifikasi Pengelompokkan Perusahaan}

\section{Penerbit obligasi Berdasarkan Kemampuan Variabel Penjelas Yang Digunakan}

Untuk menilai kemampuan prediksi dari model regresi logistik, maka digunakanlah matriks klasifikasi (Hair, et al., 1998:241). Matriks ini menghitung jumlah estimasi

\footnotetext{
12 Perusahaan besar cenderung menggunakan utang untuk membiayai investasinya (Paramu, 2006), terutama dalam proyek ekspansi yang berisiko tinggi karena jenis proyek seperti ini hanya menguntungkan pemegang saham tetapi merugikan pemberi pinjaman (Sugiarto, 2009:59). Lebih lanjut Sugiarto mengungkapkan bahwa menurut teori keagenan, jika ekspansi berhasil maka pemegang saham memperoleh hak kontrol terhadap semua nilai tambah yang dihasilkan sedangkan pemberi pinjaman memperoleh bunga pinjaman. Sebaliknya jika ekspansi gagal, pemegang saham hanya bertanggung jawab sebatas saham yang dikuasainya sedangkan pemberi pinjaman akan menanggung semua beban dana.
} 
perusahaan dikelompokkan secara tepat (correct) dan tidak tepat (incorrect) (Ghozali, 2007:238) berdasarkan variabel penjelas yang digunakannya (lihat Hair, et al., 1998:318). Matriks ini diciptakan dengan melakukan tabulasi silang pada keanggotaan kelompok aktual dengan keanggotaan kelompok prediksi (Hair, et al., 1998:241). Adapun keseluruhan kelompok observasi ini seluruhnya dapat dilihat pada matriks klasifikasi yang tersaji pada Tabel 13.

Tabel 13. Hasil Matriks Klasifikasi

\begin{tabular}{|c|c|c|c|c|c|}
\hline \multirow{2}{*}{\multicolumn{2}{|c|}{ Keterangan }} & \multirow{3}{*}{$\begin{array}{c}\begin{array}{c}\text { Jenis Kategori } \\
\text { Peringkat Obligasi }\end{array} \\
\text { Non Investment Grade }\end{array}$} & \multicolumn{2}{|c|}{ Anggota Grup Prediksi } & \multirow{3}{*}{$\begin{array}{c}\text { Total } \\
16\end{array}$} \\
\hline & & & \multirow{2}{*}{$\begin{array}{c}\text { Non Investment } \\
\text { Grade }\end{array}$} & \multirow{2}{*}{$\begin{array}{c}\text { Investment } \\
\text { Grade } \\
15 \\
\end{array}$} & \\
\hline \multirow{4}{*}{ 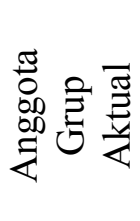 } & \multirow{2}{*}{$\begin{array}{c}\text { Jumlah } \\
\text { (unit) }\end{array}$} & & & & \\
\hline & & Investment Grade & 0 & 86 & 86 \\
\hline & \multirow{2}{*}{$\begin{array}{c}\text { Jumlah } \\
(\%)\end{array}$} & Non Investment Grade & 6,3 & 93,7 & 100 \\
\hline & & Investment Grade & 0 & 100 & 100 \\
\hline \multicolumn{5}{|c|}{ Tingkat ketepatan/akurasi klasifikasi } & $85,3 \%$ \\
\hline
\end{tabular}

Sumber: Hasil Pengolahan Data SPSS 12.0

Pada Tabel 13, terlihat jumlah perusahaan yang menerbitkan obligasi yang tergabung pada kelompok perusahaan dengan kategori bukan kelas investasi sebesar 16 perusahaan, ternyata yang sebenarnya termasuk dalam kategori peringkat bukan kelas investasi sebanyak 1 perusahaan atau terdapat kesalahan klasifikasi sebesar 15 perusahaan. Adapun jumlah perusahaan yang menerbitkan obligasi yang tergabung pada kelompok perusahaan dengan kategori kelas investasi sebesar 86 perusahaan, ternyata yang sebenarnya termasuk dalam kategori peringkat kelas investasi sebanyak 86 perusahaan atau tidak terdapat kesalahan klasifikasi. Dengan demikian, maka besarnya persentase pengklasifikasian dua kelompok peringkat perusahaan penerbit obligasi (kelompok perusahaan dengan peringkat kelas investasi dan peringkat kelas bukan investasi) dinyatakan secara benar yaitu $\frac{1+86}{102} .100 \%=$ $85,29 \% \approx 85,3 \%$.

\section{KESIMPULAN DAN SARAN}

\section{Kesimpulan}

Berdasarkan hasil pengujian hipotesis dan pembahasan yang telah dilakukan, maka terdapat beberapa hal yang dapat disimpulkan, yaitu:

1. Kebijakan utang tidak berpengaruh terhadap kemungkinan penentuan peringkat obligasi. Dengan demikian, hasil penelitian ini mengkonfirmasi hasil temuan Setyapurnama dan Norpratiwi (2009) maupun Manurung, et al. (2009). 
2. Profitabilitas berpengaruh positif terhadap kemungkinan penentuan peringkat obligasi. Dengan demikian, hasil penelitian ini mengkonfirmasi hasil temuan Kamstra, et al. (2001), Crabtree dan Maher, (2005), Amrullah (2000), maupun Manurung, et al. (2009).

3. Likuiditas tidak berpengaruh terhadap kemungkinan penentuan peringkat obligasi. Dengan demikian, hasil penelitian ini tidak konsisten dengan hasil temuan Almalia dan Devi (2007), Hasnawati dan Dirja (2008), maupun Manurung, et al. (2009).

4. Ukuran perusahaan tidak berpengaruh terhadap kemungkinan penentuan peringkat obligasi. Dengan demikian, hasil penelitian ini konsisten dengan hasil temuan Almalia dan Devi (2007), maupun Setyapurnama dan Norpratiwi (2009).

5. Status perusahaan tidak berpengaruh terhadap kemungkinan penentuan peringkat obligasi.

\section{Saran}

Berdasarkan hasil dan pembahasan yang telah dilakukan maka terdapat beberapa saran yang ditujukan pada beberapa pihak, yaitu:

1. Investor. Untuk memberikan rasa aman atas dana yang diinvestasikannya, investor dapat membeli obligasi dengan kategori peringkat investasi. Dalam memilih obligasi dengan kategori peringkat investasi, disarankan investor memilih perusahaan penerbit obligasi berdasarkan rasio profitabilitas ROA yang bernilai tinggi. Perusahaan dengan profitabilitas yang tinggi diyakini lebih dapat melangsungkan kegiatan usahanya (going concern) dari pada perusahaan yang memiliki rasio profitabilitas yang lebih rendah.

2. Perusahaan penerbit obligasi. Laba merupakan indikator yang terpenting bagi perusahaan dalam menarik modal dari luar, termasuk bagi perusahaan penerbit obligasi karena berpengaruh terhadap penentuan peringkatnya. Oleh karena itu, perusahaan harus dapat mengatur bauran/komposisi aktiva lancar dan aktiva tetap yang dimilikinya sehingga dapat menghasilkan laba secara optimal.

3. Bagi peneliti selanjutnya.

- Penelitian ini menggunakan 5 (lima) variabel penjelas dalam memprediksi peringkat obligasi. Meski demikian, hanya ROA yang menunjukkan hasil yang signifikan sedangkan keempat variabel penjelas lainnya tidak menunjukkan hasil yang signifikan. Untuk itu, maka peneliti selanjutnya dapat menggunakan variabel penjelas lainnya yang tidak digunakan dalam penelitian ini seperti risiko sistematik saham, rasio aktivitas, rasio pengkoveran bunga untuk digabungkan dalam model penelitiannya. Dengan demikian, variabel penjelas yang tidak 
diakomodir oleh penelitian ini diharapkan dapat menjelaskan peringkat obligasi dengan lebih baik lagi.

- Untuk peneliti selanjutnya dapat mengklasifikasikan emiten penerbit obligasi menjadi dua kategori status/jenis perusahaan yang lainnya melalui variabel boneka sebagai variabel penjelas, misalnya saja emiten pembentuk indeks LQ45 dan bukan, emiten pembentuk indeks kompas 100 dan yang bukan, maupun emiten pembentuk Jakarta Islamic Index dan yang bukan. Dengan demikian, akan diketahui terjadinya kekonsistenan atas variabel status/jenis perusahaan pada hasil penelitian ini dengan hasil penelitian selanjutnya sebagai faktor pendeterminasi peringkat obligasi.

\section{DAFTAR PUSTAKA}

Almalia, L.S., \& Devi, V., (2007), Faktor-Faktor Yang Mempengaruhi Prediksi Peringkat Obligasi pada Perusahaan Manufaktur yang Terdaftar di Bursa Efek Jakarta, Proceeding SMART Membaca Jaman dalam Perspektif Manajemen, 2-3 November: 164-178.

Amrullah, K., (2007), Kemampuan Rasio Keuangan sebagai Alat untuk Memprediksi Peringkat Obligasi Perusahaan Manufaktur, Skripsi S1 (Tidak Dipublikasikan), Universitas Negeri Semarang, Semarang.

Ang, J.S., Cole, R.A., \& Lin, J.W., (2000), Agency Cost and Ownership Structure, The Journal of Finance, 55 (1): 81-105.

Bouzouita, R., \& Young, A.J., (1998), A Probit Analysis of Best Ratings, Journal of Insurance Issues, 21 (1): 23-34.

Crabtree, A.D., \& Maher, J.J., (2005), Earning Predictability, Bond Rating, and Bond Yield, Review of Quantitative Finance and Accounting, 25: 233-253.

Curtchley, C.E., \& Hansen, R.S., (1989), A Test of Agency Theory of Managerial Ownership Corporate Leverage, and Corporate Dividends, Financial Management, 18: 36-46.

Elton, E.J., Gruber, M.J., Brown, S.J., \& Goetzmann, W.N., (2003), Modern Portfolio Theory and Investment Analysis, Sixth Edition, John Willey and Sons Inc., New York.

Ghozali, I., (2007), Aplikasi Analisis Multivariate dengan Program SPSS, Cetakan IV, Badan Penerbit Universitas Diponegoro, Semarang.

Hair, J.F., Anderson, R.E., Tatham, R.L., \& Black, W.C., (1998), Multivariate Data Analysis, Fifth Edition, Prentice-Hall Inc., New Jersey.

Hanafi, M.M., (2004), Manajemen Keuangan, Edisi 2004/2005, BPFE-UGM, Yogyakarta.

Hartono, J., (2004), Metodologi Penelitian Bisnis: Salah Kaprah dan PengalamanPengalaman, Edisi 2004/2005, Cetakan Pertama, BPFE-UGM, Yogyakarta.

Hartono, J., (2008), Teori Portofolio dan Analisis Investasi, Edisi Kelima, BPFE-UGM, Yogyakarta.

Hasnawati, S., \& Dirja, R., (2008), Pengaruh Faktor Current Ratio, Debt to Equity, Return On Equity, Size, dan Maturity Terhadap Prediksi Peringkat Obligasi, Jurnal Manajemen, XII (3): 255-258. 
Hermawan, A., (2006), Penelitian Bisnis: Paradigma Kuantitatif, Gramedia Widiasarana Indonesia, Jakarta.

Husnan, S., (2009), Dasar-dasar Teori Portofolio dan Analisis Sekuritas, Edisi Keempat, Cetakan Kedua, UPP STIM YKPN, Yogyakarta.

Jensen, M.C., (1986), Agency Cost of Free Cash Flow, Corporate Finance, and Takeovers, American Economic Review, 76 (2): 323-329.

Johnson, S.A., (1995), Dividend Payout and The Valuation Effect of Bonds Investment, Journal of Financial Quantitative Analysis, 30 (3): 407-423.

Kamstra, M., Kennedy, P., \& Suan, T., (2001), Combining Bond Rating Forecasts Using Logit, The Financial Review, 37: 75-96.

Karyani, E., \& Manurung, A.H., (2006), Pengaruh Pengumuman Perubahan Bond Rating Terhadap Return Saham Perusahaan di Bursa Efek Jakarta (Penelitian Periode 2003 s.d. 2005), Jurnal Riset Akuntansi Indonesia, 9 (3): 282-306.

Manurung, A. H., Silitonga, D., \& Tobing, W.R.L., (2009), Hubungan Rasio-Rasio Keuangan dengan Rating Obligasi, PT Finansial Bisnis Informasi Jakarta, Artikel ini diakses melalui $\quad$ http://www.finansialbisnis.com/Data2/Riset/rating\%20paper\%20\%20Desmon.pdf., pada tanggal 15 Desember 2009.

Martel, M.C.V., \& Padron, Y.G., (2006), Debt and Informative Content: Evidence in the Spanish Stock Market, International Research Journal of Finance and Economics, 4: 213-219.

Mutamimah, (2007), Debt Policy as Corporate Governance Mechanism In Concentrated Ownership, Jurnal Manajemen dan Bisnis, 6 (2): 127-137.

Myers, S.C., \& Maljuf, N.S., (1984), Corporate Financing and Investment Decision When Firms Have Information That Investor Do Not Have, Journal of Financial Economics, 13, (1): 187-221.

Ohlson, J.A., (1980), Financial Ratios and The Probabilistic Prediction of Bankrupcty, Journal of Accounting Research, 18 (1): 109-131.

Paramu, H., (2006), Determinan Struktur Modal: Studi Empiris Pada Perusahaan Publik di Indonesia, Manajemen Usahawan Indonesia, XXXV (11): 48-54.

Pefindo, (2010), Metodologi Rating, Artikel ini diakses melalui http://new.pefindo.com/scrm_korporasi_index.php? pada tanggal 5 Oktober 2010.

Pratomo, E.P., dan Nugraha, U., (2009), Reksa Dana: Solusi Perencanaan Investasi di Era Modern, Edisi Revisi Kedua, Penerbit PT Gramedia, Jakarta.

Purwaningsih, A., (2008), Pemilihan Rasio Keuangan Terbaik Untuk Memprediksi Peringkat Obligasi, Jurnal Bisnis dan Ekonomi KINERJA, 12 (1): 85-99.

Raharja, dan Sari, M.P., (2008), Perbandingan Alat Analisis (Diskriminan dan Regresi Logistik Terhadap Peringkat Obligasi (PT Pefindo), Jurnal Maksi, 8 (1): 87-104.

Ross, S. (1977), The Determination of Financial Structure: The Incentive - Signalling Approach, The Bell Journal of Economics, 8: 23-40.

Santosa, A.F., \& Wedari, L.K., (2007), Analisis Faktor-Faktor Yang Mempengaruhi Kecenderungan Penerimaan Opini Audit Going Concern, Jurnal Akuntansi dan Auditing Indonesia, 11 (2): 141-158.

Santoso, S., (2009), Business Forecasting Metode Peramalan Bisnis Masa Kini dengan Minitab dan SPSS, Terbitan Pertama, Penerbit PT Elex Media Komputindo, Jakarta. 
Sartono, A., (2001), Pengaruh Aliran Kas Internal dan Kepemilikan Manajer dalam Perusahaan terhadap Pembelanjaan Modal: Managerial Hypotheses atau Pecking Order Hypotheses?, Jurnal Ekonomi dan Bisnis Indonesia, 16 (1): 54-63.

Sartono, A., (2008), Manajemen Keuangan: Teori dan Aplikasi, Edisi Keempat, Cetakan Kedua, BPFE-UGM, Yogyakarta.

Setyapurnama, Y.S., \& Norpratiwi, A.M.V., (2009), Pengaruh Corporate Governance Terhadap Peringkat Obligasi, Artikel ini diakses lewat http://dwiwidiyastoto.blogspot.com/search?updatedmin=20090101T00\%3A00\%3A00$08 \% 3 \mathrm{~A} 00 \&$ updated-max $=2010-01-01 \mathrm{~T} 00 \% 3 \mathrm{~A} 00 \% 3 \mathrm{~A} 0008 \% 3 \mathrm{~A} 00 \&$ maxresults $=9$ pada tanggal 15 Desember 2009.

Shumway, T., (2001), Forecasting Bankruptcy More Accurately: A Simple Hazard Model, Journal of Business, 74 (1): 101-124.

Sugiarto, (2009), Struktur Modal, Struktur Kepemilikan Perusahaan, Permasalahan Keagenan, dan Informasi Asimetri, Edisi Pertama, Cetakan Pertama, Penerbit Graha Ilmu, Yogyakarta.

Tandelilin, E., (2010), Portofolio dan Investasi: Teori dan Aplikasi, Edisi Pertama, Penerbit Kanisius, Yogyakarta.

Van Horne, J.C., \& Wachowicz, J.M., (1995), Fundamental of Financial Management, Ninth Edition, Prentice Hall, New Jersey.

Wijaya, M.S.V., \& Hadianto, B., (2008), Pengaruh Struktur Aktiva, Ukuran, Likuiditas, dan Profitabilitas Terhadap Struktur Modal Emiten Sektor Ritel di Bursa Efek Indonesia: Sebuah Pengujian Hipotesis Pecking Order, Jurnal Ilmiah Akuntansi, 7 (1): 71-84. 


\section{Lampiran 1. Nama Perusahaan Penerbit Obligasi dan Peringkat Obligasi}

\begin{tabular}{|c|c|c|c|c|}
\hline No. & Kode & Nama Perusahaan & $\begin{array}{l}\text { Peringkat } \\
\text { Obligasi }\end{array}$ & $\begin{array}{c}\text { Kategori Peringkat } \\
\text { Obligasi }\end{array}$ \\
\hline 1. & ADHI & Adhi Karya (Persero), Tbk. & A- & Investment Grade \\
\hline 2. & ADMF & Adira Dinamika Multifinance, Tbk & AA- & Investment Grade \\
\hline 3. & AIRJ & Aetra Air Jakarta & A- & Investment Grade \\
\hline 4. & ALFA & Alfa Retailindo, Tbk. & A- & Investment Grade \\
\hline 5. & APEX & Apexindo Pratama Duta, Tbk. & $\mathrm{A}+$ & Investment Grade \\
\hline 6. & APOL & Arpeni Pratama Ocean Line, Tbk. & A & Investment Grade \\
\hline 7. & ASDF & Astra Sedaya Finance & AA- & Investment Grade \\
\hline 8. & ASGR & Astra Graphia, Tbk. & A & Investment Grade \\
\hline 9. & BASS & Bahtera Adimina Samudra, Tbk & A- & Investment Grade \\
\hline 10. & BBIA & Bank UOB Buana, Tbk. & \multicolumn{2}{|c|}{ Tidak Ada Peringkat } \\
\hline 11. & BBKP & Bank Bukopin, Tbk. & $\mathrm{A}+$ & Investment Grade \\
\hline 12. & BBMI & Bank Syariah Muamalat Indonesia, Tbk. & A- & Investment Grade \\
\hline 13. & BBNI & Bank Negara Indonesia, Tbk. & $\mathrm{BBB}$ & Investment Grade \\
\hline 14. & BBRI & Bank Rakyat Indonesia, Tbk. & $\mathrm{A}+$ & Investment Grade \\
\hline 15. & BBSM & Bank Syariah Mandiri & $\mathrm{AA}+$ & Investment Grade \\
\hline 16. & BBTN & Bank Tabungan Negara & BBB + & Investment Grade \\
\hline 17. & BCAF & BCA Finance & $\mathrm{A}+$ & Investment Grade \\
\hline 18. & BDKI & Bank DKI & $\mathrm{A}+$ & Investment Grade \\
\hline 19. & BDMN & Bank Danamon, Tbk. & A- & Investment Grade \\
\hline 20. & BDSS & Bank Sumsel & $\mathrm{AA}+$ & Investment Grade \\
\hline 21. & BETA & Beta Inti Multifinance & Baa3 & Non Investment Grade \\
\hline 22. & BEXI & Bank Ekspor Impor Indonesia & A- & Investment Grade \\
\hline 23. & BFIN & BFI Finance Indonesia, Tbk. & Baa1 & Non Investment Grade \\
\hline 24. & BFNC & Bhakti Finance & $\mathrm{Baa} 2$ & Non Investment Grade \\
\hline 25. & BJBR & Bank Jabar Banten & $\mathrm{A}$ & Investment Grade \\
\hline 26. & BJTM & Bank Jatim & A- & Investment Grade \\
\hline 27. & BLAM & Bank Lampung & BBB & Investment Grade \\
\hline 28. & BLTA & Berlian Laju Tanker, Tbk. & $\mathrm{A}+$ & Investment Grade \\
\hline 29. & BNIS & Bank Ekspor Indonesia & BBB+ & Investment Grade \\
\hline 30. & BNLI & Bank Permata, Tbk. & A & Investment Grade \\
\hline 31. & BNTB & Bank NTB & Aa3 & Investment Grade \\
\hline 32. & BRAM & Indo Kordsa, Tbk. & A- & Investment Grade \\
\hline 33. & BRNA & Berlina, Tbk. & Baa3 & Non Investment Grade \\
\hline 34. & BSDE & Bumi Serpong Damai, Tbk. & BBB & Investment Grade \\
\hline 35. & BSEC & Bhakti Securities & Baa1 & Non Investment Grade \\
\hline 36. & BSLT & Bank Sulut & $\mathrm{BBB}$ & Investment Grade \\
\hline 37. & BTEL & Bakri Telecom, Tbk. & A- & Investment Grade \\
\hline 38. & BVIC & Bank Victoria International, Tbk. & A1 & Investment Grade \\
\hline 39. & CFIN & Clipan Finance Indonesia, Tbk. & $\mathrm{A} 2$ & Investment Grade \\
\hline 40. & CLPK & Ciliandra Perkasa & A- & Investment Grade \\
\hline 41. & CMNP & Citra Marga Nusaphala Persada, Tbk. & A1 & Investment Grade \\
\hline 42. & CPIN & Charoen Pokphand Indonesia, Tbk. & BBB+ & Non Investment Grade \\
\hline 43. & DNRK & Danareksa & $\mathrm{A}$ & Investment Grade \\
\hline 44. & DUTI & Duta Pertiwi, Tbk. & BBB & Investment Grade \\
\hline
\end{tabular}


Lampiran 1. Nama Perusahaan Penerbit Obligasi dan Peringkat Obligasi (Lanjutan)

\begin{tabular}{|c|c|c|c|c|}
\hline No. & Kode & Nama Perusahaan & $\begin{array}{c}\text { Peringkat } \\
\text { Obligasi }\end{array}$ & $\begin{array}{c}\text { Kategori Peringkat } \\
\text { Obligasi }\end{array}$ \\
\hline 45. & ELTY & Bakrieland Development, Tbk. & $\mathrm{BBB}+$ & Investment Grade \\
\hline 46. & EXCL & Excelcomindo Pratama, Tbk. & AA- & Investment Grade \\
\hline 47. & FIFA & Federal International Finance & AA- & Investment Grade \\
\hline 48. & FREN & Mobile-8 Telecom, Tbk & $\mathrm{BBB}+$ & Investment Grade \\
\hline 49. & HITS & Humpuss Itermoda Transportasi, Tbk. & A1 & Investment Grade \\
\hline 50. & HMSP & Hanjaya Mandala Sampoerna, Tbk. & AAA & Investment Grade \\
\hline 51. & IATG & Infoasia Teknologi Global, Tbk. & $\mathrm{Ba} 2$ & Non Investment Grade \\
\hline 52. & IDSR & Indosiar Visual Mandiri, Tbk. & $\mathrm{BB}+$ & Non Investment Grade \\
\hline 53. & IJPA & Indo Jasa Pratama, Tbk. & Baa2 & Non Investment Grade \\
\hline 54. & INDF & Indofood Sukses Makmur, Tbk. & $\mathrm{AA}+$ & Investment Grade \\
\hline 55. & INKP & Indah Kiat Pulp \& Paper, Tbk. & $\mathrm{D}$ & Non Investment Grade \\
\hline 56. & ISAT & Indosat, Tbk. & $\mathrm{AA}+$ & Investment Grade \\
\hline 57. & JPFA & JPFA Comfee & $\mathrm{BBB}+$ & Investment Grade \\
\hline 58. & JPOS & os & A & Investment Grade \\
\hline 59. & JPRO & Jakarta Propertindo, Tbk. & Baa2 & Non Investment Grade \\
\hline 60. & JSMR & Jasa Marga Persero, Tbk. & AA- & Investment Grade \\
\hline 61. & KLBF & Kalbe Farma, Tbk. & $\mathrm{AA}$ & Investment Grade \\
\hline 62. & KREN & Kresna Graha Sekurindo, Tbk. & A3 & Investment Grade \\
\hline 63. & LPPI & Lontar Papyrus Pulp \& Paper Industry & $\mathrm{D}$ & Non Investment Grade \\
\hline 64. & LTLS & Lautan Luas, Tbk. & A- & Investment Grade \\
\hline 65. & MAIN & Malindo F & $\mathrm{A}+$ & Investment Grade \\
\hline 66. & MASP & Maspion, Tbk. & A- & Investment Grade \\
\hline 67. & MAYA & Bank Mayapada Internasional, Tbk. & Baa1 & Non Investment Grade \\
\hline 68. & MEDC & Medco Energi Internasional, Tbk. & AA- & Investment Grade \\
\hline 69. & MEGA & Bank Mega, Tbk & A & Investment Grade \\
\hline 70. & MLSS & Muliaglass & \multicolumn{2}{|c|}{ Tidak Ada Peringkat } \\
\hline 71. & MPPA & Matahari Putra Prime & $\mathrm{A}+$ & Investment Grade \\
\hline 72. & MYOR & Mayora Indah, Tbk. & $\mathrm{A}+$ & Investment Grade \\
\hline 73. & NEFI & Newera Footwear In & \multicolumn{2}{|c|}{ Tidak Ada Peringkat } \\
\hline 74. & NISP & Bank NISP, Tbk. & $\mathrm{A}+$ & Investment Grade \\
\hline 75. & OTMA & Oto Multiartha & $\mathrm{A}+$ & Investment Grade \\
\hline 76. & PANS & Panin Sekuritas, Tbk. & A1 & Investment Grade \\
\hline 77. & PIDL & Pindo Deli Pulp and Paper Mills & $\mathrm{D}$ & Non Investment Grade \\
\hline 78. & PJAA & Pembangunan Jaya Ancol, Tbk. & $\mathrm{A}+$ & Investment Grade \\
\hline 79. & PLJA & Pam Lyonnaise Jaya & A- & Investment Grade \\
\hline 80. & PNBN & Bank Pan Indonesia, Tbk. & A & Investment Grade \\
\hline 81. & PPGD & Perum Pegadaian & AA & Investment Grade \\
\hline 82. & PPLN & Perusahaan Listrik Negara Persero & $\mathrm{Aa} 2$ & Investment Grade \\
\hline 83. & PTPN & Perkebunan Nusantara III Persero & AA- & Investment Grade \\
\hline 84. & PTPV & Perkebunan Nusantara V Persero & A & Investment Grade \\
\hline 85. & PVII & Perkebunan Nusantara VII Persero & A & Investment Grade \\
\hline
\end{tabular}


Lampiran 1. Nama Perusahaan Penerbit Obligasi dan Peringkat Obligasi (Lanjutan)

\begin{tabular}{|c|l|l|c|l|}
\hline No. & Kode & \multicolumn{1}{|c|}{ Nama Perusahaan } & $\begin{array}{c}\text { Peringkat } \\
\text { Obligasi }\end{array}$ & \multicolumn{1}{|c|}{ Kategori } \\
\hline 86. & PWON & Pakuwon Jati, Tbk. & BBB- & Investment Grade \\
\hline 87. & RCTI & Rajawali Citra Televisi Indonesia & A & Investment Grade \\
\hline 88. & RENT & CSM Corporatama & Ba1 & $\begin{array}{l}\text { Non Investment } \\
\text { Grade }\end{array}$ \\
\hline 89. & RICY & Ricky Putra Globalindo, Tbk. & Baa1 & $\begin{array}{l}\text { Non Investment } \\
\text { Grade }\end{array}$ \\
\hline 90 & RMBA & Bentoel International Investama, Tbk. & A & Investment Grade \\
\hline 91. & RUIS & Radiant Utama Interinsco, Tbk. & A3 & Investment Grade \\
\hline 92. & SBTR & Semen Baturaja & A3 & Investment Grade \\
\hline 93. & SCTV & Surya Citra Televisi & A & Investment Grade \\
\hline 94. & SIFC & Swadarma Indotama Finance & BBB- & Investment Grade \\
\hline 95. & SMRA & Summarecon Agung Tbk. & A- & Investment Grade \\
\hline 96. & SOFN & Summit Ottofinance & AAA & Investment Grade \\
\hline 97. & SONA & Sona Topas Tourism Industry, Tbk. & A1 & Investment Grade \\
\hline 98. & TKIM & Pabrik Kertas Tjiwi Kimia, Tbk. & BBB- & Investment Grade \\
\hline 99. & TRAC & Serasi Autoraya & A- & Investment Grade \\
\hline 100. & TRIM & Trimegah Securities, Tbk. & A- & Investment Grade \\
\hline 101 & TRJE & Truba Jaya Enginnering & BBB+ & Investment Grade \\
\hline 102. & TUFI & Tunas Financindo Saraba & A- & Investment Grade \\
\hline 103. & UNIC & Unggul Indah Cahaya, Tbk. & A- & Investment Grade \\
\hline 104. & WOMF & Wahana Ottomitra Multiartha, Tbk. & A- & Investment Grade \\
\hline 105. & WSKT & Waskita Karya & BBB+ & Investment Grade \\
\hline
\end{tabular}

